\title{
Pleistocene Bovidae (Mammalia) from Malapa, Gauteng Province, South Africa
}

\author{
Juliet K. Brophy, Darryl J. de Ruiter, Mikael Fortelius, \\ Marion Bamford, and Lee R. Berger
}

\begin{abstract}
This study presents an analysis of the collection of Bovidae (Mammalia: Artiodactyla) currently available from the Australopithecus sediba-bearing site of Malapa, Gauteng Province, South Africa. The assemblage consists of partially articulated and closely associated skeletal elements. Estimates of ontogenetic age and, when possible, body mass were made based on the postcrania. The bovids are represented by a minimum number of 13 individuals, four of which have been identified below the Tribe level including Makapania broomi, Tragelaphus scriptus, Megalotragus sp., and Antidorcas recki. The sample size of the bovids is small, therefore only a preliminary paleoenvironmental reconstruction is indicated. The paleoenvironment is consistent with reconstructions of nearby sites in the Cradle of Humankind, including a mosaic of grasslands and more extensive woodlands than historically recorded for the area. A permanent water source is also indicated. Taphonomic analysis of the bovid remains demonstrates bone breakage patterns indicative of dry, post depositional fractures. The bones do not exhibit marks particular to a bone accumulating agent. Despite the small sample size, the taphonomic analyses support the reconstruction of Malapa as a vertical death trap. These results suggest that the remains were buried and fossilized in a manner similar to the hominins, supporting a common origin for the hominin and non-hominin fauna ca. 1.977 million years ago. Over a relatively short span of time complete bovid individuals, alongside the individuals of $A$. sediba, entered the vertical death trap of Malapa, either accidentally or of their own volition, and ultimately became fossilized.
\end{abstract}

Juliet K. Brophy. Department of Geography and Anthropology, Louisiana State University, Baton Rouge, Louisiana and Evolutionary Studies Institute, University of Witwatersrand, Johannesburg, South Africa. jbrophy@lsu.edu

Darryl J. de Ruiter. Evolutionary Studies Institute, University of Witwatersrand, Johannesburg, South Africa and Department of Anthropology, Texas A\&M University, College Station, Texas. deruiter@tamu.edu Mikael Fortelius. Department of Geosciences and Geography, Institute of Biotechnology; Finnish Museum of Natural History. mikael.fortelius@helsinki.fi

Marion Bamford. Evolutionary Studies Institute, University of Witwatersrand, Johannesburg, South Africa. marion.bamford@wits.ac.za

Brophy, Juliet K., de Ruiter, Darryl J., Fortelius, Mikael, Bamford, Marion, and Berger, Lee R. 2016. Pleistocene Bovidae (Mammalia) from Malapa, Gauteng Province, South Africa. Palaeontologia Electronica 19.2.16A: 1-22

palaeo-electronica.org/content/2016/1463-bovidae-from-malapa

Copyright: Palaeontological Association June 2016 
Lee R. Berger. Evolutionary Studies Institute, University of Witwatersrand, Johannesburg, South Africa. profleeberger@yahoo.com

Keywords: Bovidae; Malapa; Taphonomy; Early Pleistocene

Submission: 4 December 2015 Acceptance: 11 April 2016

\section{INTRODUCTION}

Australopithecus sediba has to date been recovered from the site of Malapa, South Africa, in the Cradle of Humankind approximately $15 \mathrm{~km}$ NNE of sites Sterkfontein and Swartkrans in Gauteng Province, South Africa (Berger et al., 2010). The site has yielded two well-preserved and relatively complete hominin skeletons that have been described as possibly representing a transitional form linking australopiths and later Homo. The Malapa cave deposits are divided into five sedimentary facies, A-E (see Dirks et al., 2010). The geological context suggests that the hominins were buried in a single debris flow that encased the fossils in a clastic karstic matrix soon after deposition. This event is represented in Facies D and E. The skeletons and associated fauna date to $1.977 \pm 0.0015$ m.y.a. (Pickering et al., 2011).

The purpose of this research is to provide some paleoecological context for $A$. sediba. Specifically, this paper presents information on animals in the Family Bovidae that are associated with the hominins. Bovids are the most abundant fauna at the site; approximately 254 cranial and postcranial remains have been recovered so far. While this number is small relative to other South African sites, several specimens are represented by complete skeletal elements and articulated, partial skeletons. This paper provides an in-depth analysis of the current sample of bovid craniodental and postcranial remains. The paper also includes a discussion on the taphonomic analyses of the bovid postcranial remains in order to assess accumulating agent signature marks and fracture patterns. Ultimately, the paper provides information about the bovid species that existed during the time of $A$. sediba and about the formation of the assemblage at Malapa.

\section{MATERIALS AND METHODS}

The fossil material was recovered from Malapa Facies $D$ and $E$ in blocks of clastic sediment and housed in the University of Witwatersrand. The Malapa bovids were analyzed and their taxonomic affiliations were recorded to their lowest confident taxonomic level using the modern and fossil comparative collections held in the Evolutionary Studies Institute at the University of Witwatersrand, Johannesburg, and the Ditsong National Museum of Natural History in Pretoria, South Africa.

\section{Cranium}

In addition to relying on comparative collections, several studies were performed on the teeth in order to aid in taxonomic identifications and to investigate feeding ecology. These studies include Elliptical Fourier Function Analysis (EFFA) and analyses on the phytoliths and mesowear of the teeth. EFFA is a curve-fitting morphometric program particularly suited for the characterization of boundary outline data (Lestrel, 1989). For this study, EFFA was applied to the occlusal surface of bovid teeth in order to aid in their taxonomic identification. To achieve this, two-dimensional outlines of the occlusal surface of bovid maxillary and mandibular molars that preserve a majority of their surface $(>85 \%)$ were obtained using the digitizing program MLmetrics, and the data were imported into EFFA (see Brophy, 2011; Brophy et al., 2014). The program quantifies the surface of the molar by computing harmonics and amplitudes that describe their overall form (size and shape) (Wolfe et al., 1999). The amplitudes of the harmonics were compared using discriminant function analysis (DFA) with a previously established bovid reference sample that includes 20 extant species from seven different tribes (Table 1). This process uses predictive analytics to provide an estimate of the probability that a Malapa specimen belongs to a specific tribe and genus/species. Fossils with a typical probability of $>0.15$ were considered members of that taxonomic group, a threshold that has been previously established (Brophy, 2011). It is important to predict both of these levels (i.e., tribe and genus/species) because while a tooth might classify into a tribe with a high probability, it may represent an extinct species or an extant species not in the reference database. The purpose of performing this test is to aid in taxonomic identification. Significant overlap exists in the form of the occlusal surface of 
TABLE 1. Extant bovid species in the previously established reference sample for Elliptical Fourier Function Analysis (Brophy, 2011).

\begin{tabular}{cl}
\hline Tribe & \multicolumn{1}{c}{ Species } \\
\hline Alcelaphini & Connochaetes taurinus \\
& Connochaetes gnou \\
& Alcelaphus buselaphus \\
& Damaliscus dorcas \\
Tragelaphini & Taurotragus oryx \\
& Tragelaphus strepsiceros \\
& Tragelaphus scriptus \\
Bovini & Syncerus caffer \\
Reduncini & Redunca arundinum \\
& Redunca fulvorufula \\
& Kobus leche \\
& Kobus ellipsiprymnus \\
& Hippotragus niger \\
Hippotragini & Hippotragus equinus \\
& Oryx gazella \\
& Raphicerus campestris \\
& Oreotragus oreotragus \\
Antilopini & Pelea capreolus \\
& Ourebia ourebi \\
& Antidorcas marsupialis \\
\hline
\end{tabular}

bovid teeth. The program quantifies the occlusal surface of the tooth and allows it to be compared with the reference database. While the tooth might represent an extinct species, similarities exist in teeth that are in the same tribe; therefore, EFFA can be used to help identify a tooth at the tribe and genus/species level.

Analyses of the phytoliths were performed on a sample of bovid teeth in order to determine if phytoliths could be recovered and used to aid in identifications and to obtain information on their feeding ecology. Plants produce silica bodies, or phytoliths, that maintain morphology specific to taxa. With good preservation, these biogenic silica bodies can be recovered from the dental calculus of bovid teeth and used to assess diet (see Piperno, 2006; Henry et al., 2012). In the palynology laboratory at the University of Witwatersrand, phytoliths were extracted from the calculus using the following method: a $10 \%$ solution of sodium hexameta- phosphate (Calgon) was added to each sample to deflocculate the calculus and assist diffusion. After 24 hours, the sample was sonicated for 5 minutes, centrifuged at $2000 \mathrm{rpm}$ for $2 \mathrm{~min}$ utes, and the supernatant removed. Next, the sam- ple was rinsed twice with distilled water. To dissolve the calculus, a $10 \%$ solution of hydrochloric acid was added and left for approximately 12 hours, and then rinsed twice in distilled water (see Henry et al., 2012). The remaining sample was mounted on a microscope slide in a 1:4 glycerine/ water solution and examined under a light microscope at $400 \times$ magnification. Identified phytoliths are described using the terms recognized by the International code for phytolith nomenclature by using their geometric shapes and, when possible, texture/ornamentation and anatomical origin (see Madella et al., 2005 for full list).

While proper analysis of the mesowear is excluded by the small sample size, qualitative analyses of palaeodiet based on the mesowear approach were performed on the bovid teeth. These analyses rely on occlusal relief and cusp shape as reflections of the amount of attrition and abrasion that occurred on the occlusal surfaces of the tooth due to diet. Mesowear was recorded by examining the buccal (maxillary) and lingual (mandibular) apices of molar tooth cusps and scoring them as being sharp, rounded, or blunt depending on the degree of facet development. Sharp cusps usually indicate browsers, rounded cusps suggest mixed feeders, and blunt cusps tend to represent grazers. The space between the cusps is recorded as being either high or low and indicates a browser or grazer, respectively (Fortelius and Solunias, 2000).

\section{Postcranium}

The age, side, body size class (BSC), and degree of completeness were documented for each bovid element. The body mass of a BSC I bovid is <23 kg., BSC II 23-84 kg., BSC III 84-296 kg., and BSC IV >296 kg (Brain, 1981). The skeletal part representation was determined by analyzing the number of identified specimens (NISP) for each element, the minimum number of elements (MNE) those specimens comprise, and the comprehensive minimum number of individuals (CMNI) they encompass while considering factors such as age, side, size, and sex, a method outlined by Bunn (1982). The postcranial elements were compared with bovid long bone data presented in Scott (1985) and Swanepoel and Steyn (2011).

The limb bones were examined systematically for the identification of any pre, peri, or postmortem taphonomic processes. Specifically, the surface modification and fracture pattern were documented for each bone. The surface modification options outlined by Behrensmeyer (1978) and White 
(1992) include: cut marks, hammerstone percussion, cortical peeling, pathology, punctuate depressions, root etching, scooping or hollowing, gastric etching, tooth notches, tooth pitting, tooth scoring, carnivore damage, cracks, trowel damage, sedimentary abrasion, and evidence of being scooped/ hollowed, eroded, chewed, crushed, flattened, rotted, burnt, or gnawed by rodents or porcupines. This analysis aids in identifying what, if any, biotic or abiotic agents played a role in the accumulation of the assemblage.

Finally, the breakage patterns of the bones as defined by Villa and Mahieu (1991) were recorded for each specimen. These patterns include the fracture angle, fracture outline, shaft circumference, and degree of shaft fragment completeness. Villa and Mahieu (1991) describe the fracture angle as the angle exhibited by the fracture surface and the bone cortical surface. These breakages fall into one of three descriptive categories: oblique, right, and intermediate. Oblique fracture angles, defined as obtuse or acute, are indicative of green, perimortem fractures while right angled fractures suggest dry, post depositional breakages. The fracture outline involves the shape of the broken bone edge and also includes three separate categories: transverse, curved, and intermediate. Transverse breakages are perpendicular to the shaft of the bone and associated with post depositional processes. Curved breakages refer to spiral or partially spiral fractures, represent "complex, multidimensional morphologies," and usually associated with perimortem fractures with some exceptions (Villa and Mahieu, 1991). Specifically, several analysts highlight how postmortem spiral fractures can result from weathering, carnivore damage, and hominin percussion (Haynes, 1983; Villa and Mahieu, 1991; White, 1992). The shaft circumference involves diagnosing how complete the bone circumference is $(1 / 4,1 / 2,3 / 4$, or 1$)$ at any point along that bone fragment. Complete circumferences suggest in situ, postmortem breakages while less complete shaft circumferences tend to signify perimortem fractures. These fractures help identify whether carnivores manipulated the assemblage by attacking limb bone epiphyses and by leaving behind the diaphyses with complete circumferences. Less complete shaft circumferences can be indicative of fractures at the time of death, hominin manipulation, and/or abiotic processes such as sediment compaction. The degree of shaft completeness refers to what percentage of the entire bone remains. Complete or mostly complete bones suggest that little to no modification affected the bone prior to deposition. This research expands on Val et al. (2015), which included a taphonomic analysis of the entire vertebrate assemblage of Malapa. This paper provides complimentary taphonomic analyses that focus solely on specimens in the Family Bovidae. The specific results provided in this paper provide a more in depth analysis of the bovids, which are comparable with the more general results of the entire assemblage from Val et al. (2015).

\section{RESULTS}

A minimum of 13 individuals were recovered representing four different tribes (Table 2). Approximately 236 specimens could not be identified below Bovidae Indeterminate.

\section{Systematic Paleontology}

Family BOVIDAE Gray, 1821

Subfamily CAPRINAE Gray, 1821

Tribe OVIBOVINI Gray, 1872

Genus MAKAPANIA Wells and Cooke, 1956

Makapania broomi Wells and Cooke, 1956

Material. Two specimens represent Makapania broomi at Malapa. UW 88-929 from Block B025 consists of a distorted partial skull with complete left and right maxillary dentition and right mandibular dentition (Figure 1). Specimen UW 88-797 is a maxillary fragment with a right $\mathrm{M}^{1}$ and $\mathrm{M}^{2}$ (Figure 2).

Description. Both specimens are hypsodont, demonstrate simple central cavities where exposed, and v-shaped mesial lobes characteristic of Makapania broomi (Table 3) (Wells and Cooke, 1956). The maxillary teeth also possess large central infundibula and lack basal pillars. The right mandibular dentition of UW 88-929 consists of broken enamel outline and roots of $P_{2}$, and $P_{3}, P_{4}, M_{1}$, $M_{2}$, and $M_{3}$. No goat fold or basal pillars are evident though Brink (1999) states that the absence of goat folds is not unusual. Results of the typicality probability from EFFA were too low to help identify this specimen to a taxonomic group; this result is likely due to the fact that no Ovibovini tribe members are in the reference sample (Brophy, 2011).

Comparisons. The Malapa specimens were compared with the type specimen, M 162, and specimen M 8227 of Makapania broomi from Makapansgat housed at the University of Witwatersrand. Makapania cf. broomi specimens from Sterkfontein Member 4 including STS 1721, STS 2059, and STS 1564 were also studied at the Ditsong National Museum of Natural History. The 
TABLE 2. Bovidae remains from Malapa, South Africa. NISP = Number of Identified Specimens; MNI = Minimum Number of Individuals

\begin{tabular}{|c|c|c|c|c|c|}
\hline $\begin{array}{l}\text { Order Artiodactyla } \\
\text { Family Bovidae }\end{array}$ & & & & NISP & MNI \\
\hline & Subfamily Caprinae & Tribe Ovibovini & & & \\
\hline & & & Makapania broomi & 2 & 2 \\
\hline & Subfamily Bovinae & Tribe Tragelaphini & & & \\
\hline & & & Tragelaphus scriptus & 3 & 1 \\
\hline & $\begin{array}{l}\text { Subfamily } \\
\text { Alcelaphinae }\end{array}$ & Tribe Alcelaphini & & & \\
\hline & & & Alcelaphini Indeterminate & 2 & 2 \\
\hline & & & Megalotragus sp. & 8 & 5 \\
\hline & Subfamily Antilopinae & Tribe Antilopini & & & \\
\hline & & & Antidorcas recki & 2 & 2 \\
\hline & & $\begin{array}{l}\text { Antilopinae } \\
\text { indeterminate }\end{array}$ & & 1 & 1 \\
\hline Bovidae Indeterminate & & & & 236 & \\
\hline
\end{tabular}

Malapa specimens overlap in size and shape with the Makapansgat and Sterkfontein materials.

The Malapa specimens were also compared to Makapania sp. specimens from the Gladysvale Extension Site (GVED) (e.g., GV 5288, GV 8266,
GV 8410) and via photographs and measurements to the cf. Makapania sp. fossils from Swartkrans (SK) Members 1 including SK 3005, SK 3123, and 3150 (Vrba, 1976; Brain, 1981; Lacruz et al., 2002). The SK and GVED fossils are slightly

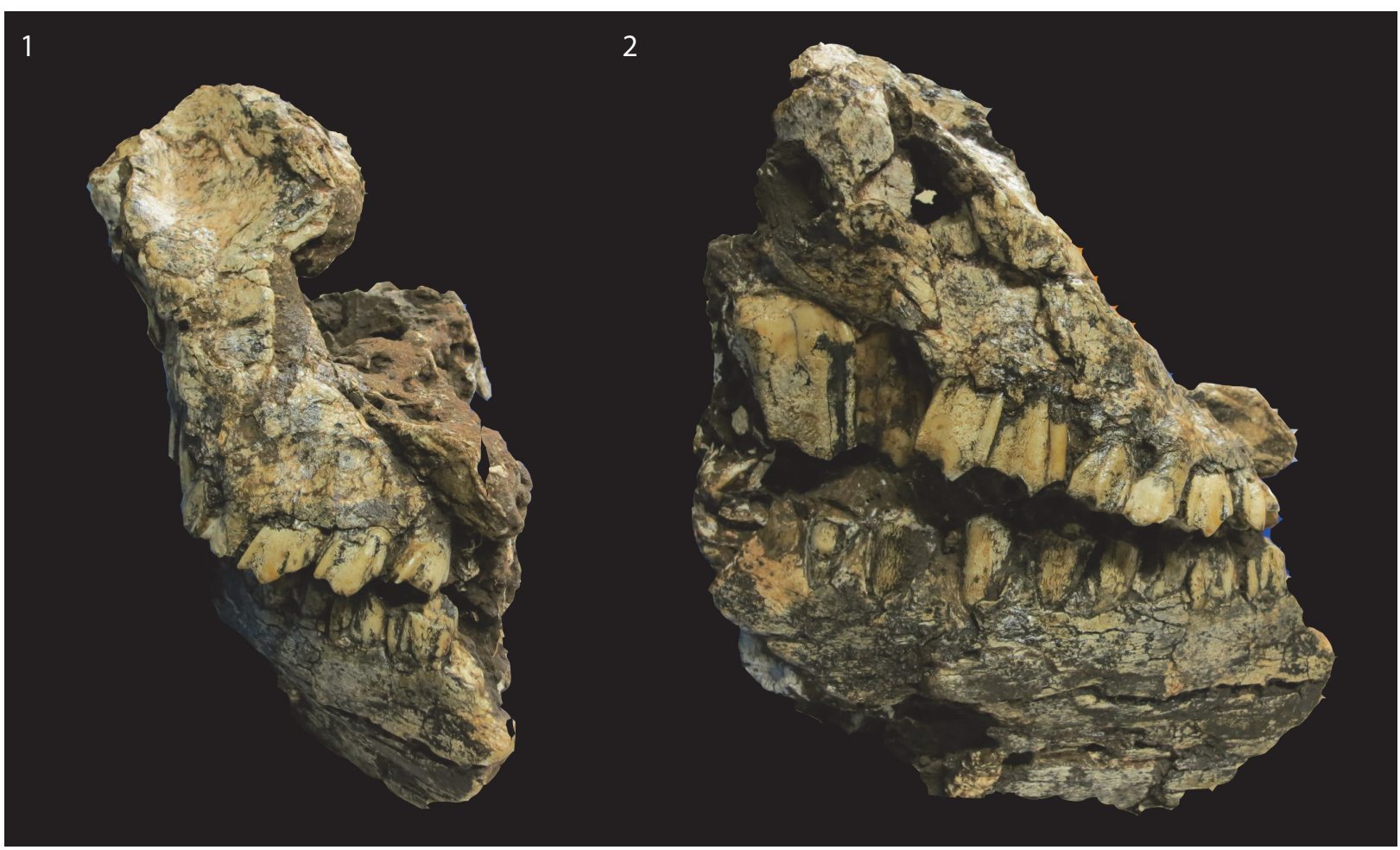

FIGURE 1. Anterior (left) and lateral (right) view of UW 88-929, Makapania broomi. 


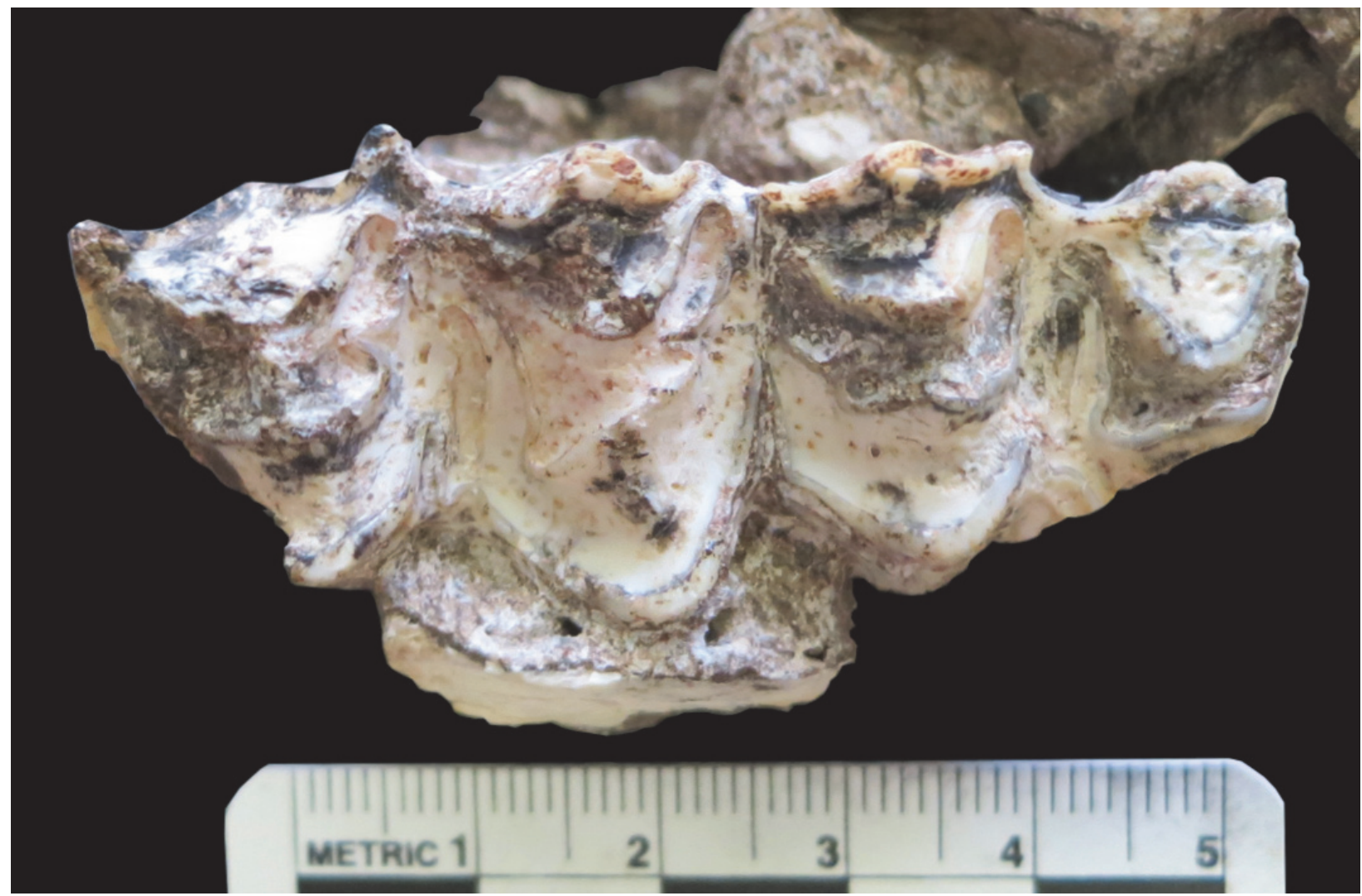

FIGURE 2. UW 88-797 maxillary fragment with a right $\mathrm{M}^{1}$ and $\mathrm{M}^{2}$.

smaller than $M$. broomi but maintain the morphological characteristics outlined in Wells and Cooke (1956). The Malapa bovid specimens are bigger than the SK and GVED specimens and consistent in size and shape with Makapansgat M. broomi.

Subfamily BOVINAE Gray, 1821

Tribe TRAGELAPHINI Blythe, 1863

Genus TRAGELAPHUS Blainville, 1816

Tragelaphus scriptus Pallas, 1766

Material. Tragelaphus scriptus is represented by a right mandible that was refit from three broken pieces: UW 88-519, UW 88-518, and UW 1015 (Figure 3). UW 88-519 is a right mandibular fragment with an $\mathrm{M}_{3}$. UW 88-518 consists of a mandible with right $M_{1}$ and $M_{2}$ while UW 88-1015 is a mandibular fragment with the roots of $P_{3}$ and $P_{4}$.

Description. The mandibular teeth are brachydont and reveal simple central cavities (Table 4). No basal pillars are present on the specimens. All of the teeth are in full eruption and exhibit narrowly pointed mesial and distal lobes on the buccal side. The third molar of UW 88-519 was complete enough to perform EFFA. DFA classified the third molar as $T$. scriptus with a 0.656 typicality probability. The distal $M_{2}$ lobe of UW $88-518$ is broken, and
TABLE 3. Estimated mesiodistal (MD) measurements of Makapania broomi specimen UW 88-929 in mm.

\begin{tabular}{cccc}
\hline Maxillary & Right & MD & Left \\
\hline $\mathrm{M}^{3}$ & 32.14 & $\mathrm{M}^{3}$ & 33.07 \\
$\mathrm{M}^{2}$ & 28.78 & $\mathrm{M}^{2}$ & 29.19 \\
$\mathrm{M}^{1}$ & 22.14 & $\mathrm{M}^{1}$ & 22.86 \\
$\mathrm{P}^{4}$ & 14.58 & $\mathrm{P}^{4}$ & 14.57 \\
$\mathrm{P}^{3}$ & 13.81 & $\mathrm{P}^{3}$ & 13.7 \\
$\mathrm{P}^{2}$ & 13.32 & $\mathrm{P}^{2}$ & 9.7 \\
Mandibular & & & \\
$\mathrm{M}_{3}$ & 38.35 & & \\
$\mathrm{M}_{2}$ & 29.01 & & \\
$\mathrm{M}_{1}$ & 22.86 & & \\
$\mathrm{P}_{4}$ & 14.75 & & \\
$\mathrm{P}_{3}$ & 12.81 & \\
$\mathrm{P}_{2}$ & 10.61 & \\
\hline
\end{tabular}




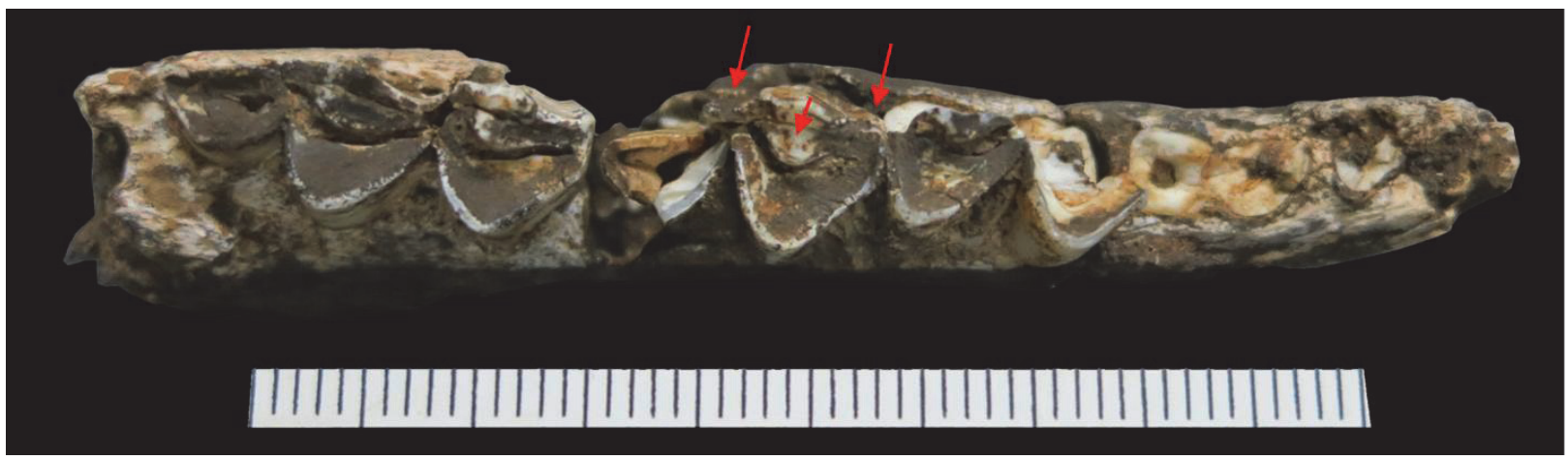

FIGURE 3. Occlusal surface of Malapa UW 88-518, UW 88-519, and UW 88-1015 refit together. The arrows are illustrating the mesostylid, paraconid, and parastylid, from left to right.

only part of the root and infundibulum remain. The mesial lobe is complete and demonstrates a strong parastylid, mesostylid, and paraconid making a distinct rib, which is consistent with $T$. scriptus (Figure 3 ). The mesial and distal lobes of the $M_{1}$ are broken; the lingual enamel face is missing. Both lobes retain buccal enamel, dentin, and infundibula.

Comparisons. The Malapa T. scriptus mandible and dentition were compared with the holotype, $\mathrm{M}$ 18, and paratype, $\mathrm{M} 19$, of the extinct $T$. pricei from Makapansgat Member 3 (Figure 4) (Wells and Cooke, 1956). The Malapa specimens resemble both $T$. pricei and $T$. scriptus. The depth of the mandible at $\mathrm{M}_{2} / \mathrm{M}_{3} /$ lower molar row (MD/MR) was

TABLE 4. Mesiodistal (MD) and buccolingual (BL) measurements in $\mathrm{mm}$ of Malapa UW 88-519, UW 88-518, UW 88-1015, M18, and M19.

\begin{tabular}{llcc}
\hline & & MD & BL \\
\hline$M_{3}$ & $88-519$ & 18.82 & 6.73 \\
& M18 & 17.54 & 6.24 \\
& M19 & 19.1 & 7.65 \\
$M_{2}$ & $88-518$ & N/A & N/A \\
& M18 & 12.68 & 6.8 \\
& M19 & 13.07 & 8.24 \\
$M_{1}$ & M1 (88-518) & 12.47 & 7.52 \\
& M18 & 11.29 & 6.77 \\
& M19 & 11.22 & 7.91 \\
$\mathrm{P}_{4}$ & P4 (88-1015) roots & 9.03 & 4.97 \\
& M18 & 9.88 & 4.87 \\
& M19 & 10.52 & 5.86 \\
$\mathrm{P}_{3}$ & P3 (88-1015) roots & 7.52 & 5.12 \\
& M18 & 8.13 & 4.33 \\
& M19 & N/A & N/A \\
& & &
\end{tabular}

compared with $T$. scriptus and T. pricei indices from Sponheimer et al. (1999). The Malapa MD/MR is approximately 0.54 , which overlaps with the range of both $T$. pricei $(0.52 \pm 0.06)$ and $T$. scriptus $(0.51 \pm 0.053)$. In fact, the two species overlapped within two standard deviations on every index in Sponheimer et al. (1999). In the absence of a method for clearly differentiating between the two species, the Malapa specimens are conservatively identified to $T$. scriptus. In addition, the Malapa specimens are comparable to SK 14205 and SK 2329 from Swartkrans Member 2 which Vrba (1976) suggests is Tragelaphus cf. scriptus and describes as indistinguishable from $T$. scriptus. de Ruiter (2003) reclassified the Swartkrans specimens as $T$. scriptus. Therefore, the Malapa specimens are conservatively identified as $T$. scriptus.

\section{Subfamily ALCELAPHINAE de Rochebrune, 1883 \\ Tribe ALCELAPHINI de Rochebrune, 1883 \\ Genus MEGALOTRAGUS van Hoepen, 1932 MEGALOTRAGUS sp.}

Material. Eight specimens exhibit morphological characteristics consistent with Megalotragus sp., an extinct giant alcelaphine. UW 88-1299 consists of a right maxillary fragment with a $\mathrm{M}^{2}$ and $\mathrm{M}^{3}$ (Figure 5). UW 88-1205 consists of a left maxillary fragment with a $\mathrm{M}^{1}$ (Figure 5). UW 88-746 is a maxillary fragment of a subadult with a left $\mathrm{M}^{2}$ and an erupting $\mathrm{M}^{3}$ (Figure 6). Malapa UW $88-1311$ is an isolated, right $\mathrm{P}^{4}$.

Four mandibular fragments were recovered from Malapa that represent Megalotragus sp. UW 88-1249 and UW 88-1250 are right and left mandibular fragments lying adjacent to each other in the matrix suggesting they are the same individual. The right mandibular fragment, UW 88-1249, consists of the hypoconulid of a broken $\mathrm{M}_{3}$ and part of the horizontal and ascending ramus. UW 88-1250 


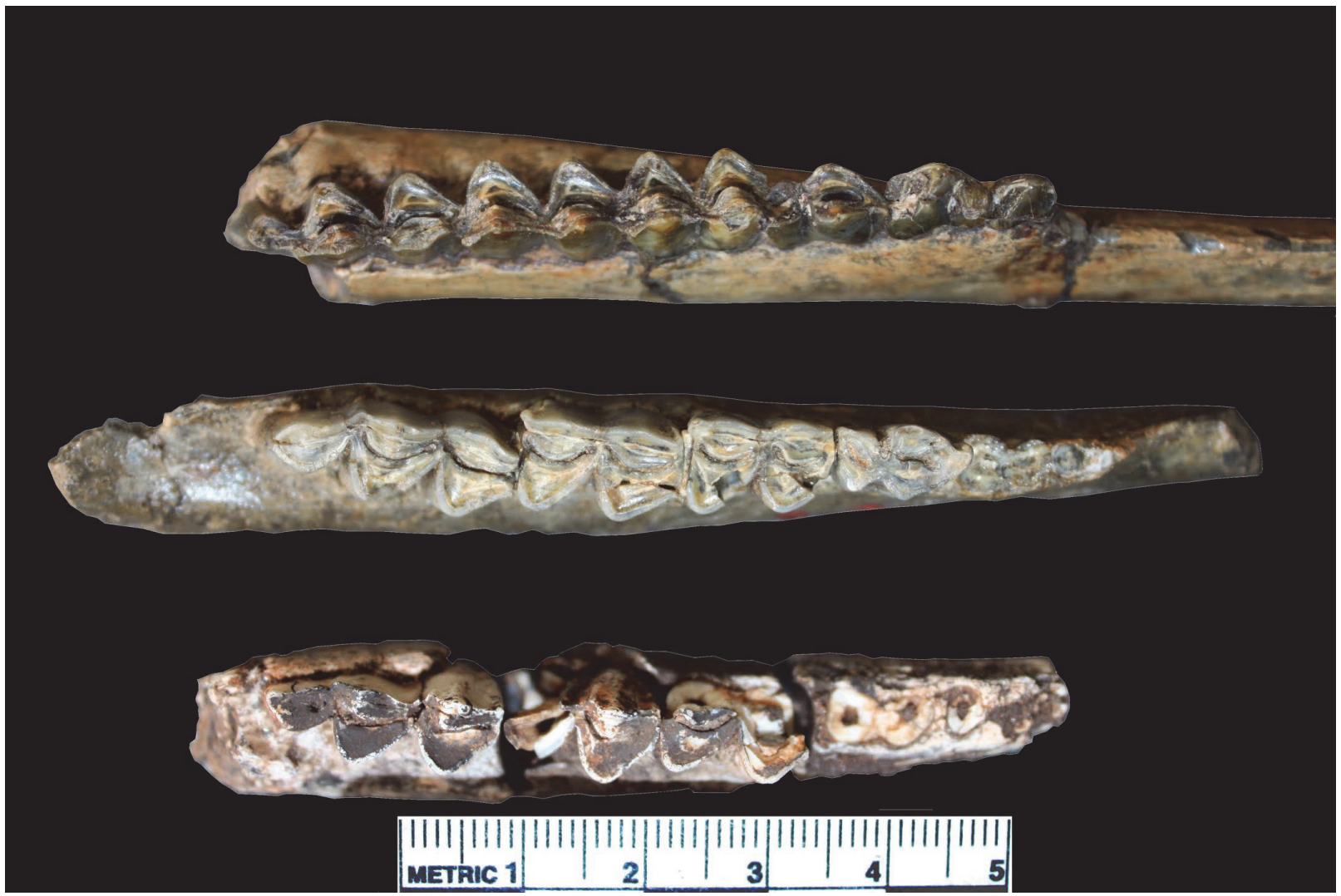

FIGURE 4. Comparison of holotype M 18 (top) and paratype M 19 (center) of $T$. pricei with Malapa mandible (bottom).

consists of the mandibular fragment surrounding the left $P_{3}, P_{4}$, and $M_{1}$. The third specimen is a left mandible fragment with an unerupted $P_{4}$, UW 88556. UW 88-1251 is an almost complete right mandible with $\mathrm{dp}_{3}, \mathrm{dp}_{4}, \mathrm{M}_{1}, \mathrm{M}_{2}, \mathrm{M}_{3}$ (Figure 7).

Description. The teeth are hypsodont and have simple infundibula, rounded lingual maxillary lobes, moderately pointy buccal mandibular lobes, and moderately well-developed ribs and styles. While broken, the metastyle of the $\mathrm{M}^{3}$ of UW 88-1299 appears to expand distally, a characteristic of Megalotragus sp. (Brink, 2005). Both of the UW 881299 molars are damaged making direct metric comparison difficult. The occlusal surface of UW 88-1205 is complete enough for EFFA to be performed. The results of the DFA classified UW 881205 as Alcelaphini with a 0.029 typicality probability at the tribe level and as Alcelaphus buselaphus with a 0.005 typicality at the species level. These results suggest that this specimen is most similar to the tribe Alcelaphini. However, the low species level typicality suggests that the occlusal outline of UW 88-1205 is not typical of one of the four extant alcelaphines in the reference database. EFFA classified the $\mathrm{M}^{2}$ of UW 88-746 as Alcelaphini with a
0.417 typicality probability and as Connochaetes taurinus with a 0.102 typicality. These results suggest that UW 88-746 is an alcelaphine but not one of the four reference species. The $M_{3}$ hypoconulid of UW 88-1249 is clearly hypsodont. The $\mathrm{P}_{4}$ hypoconid of UW 88-1250 and UW 88-556, while partially obstructed, is hyper-robust. EFFA classified the $M_{1}$ of UW 88-1251 as belonging to the tribe Alcelaphini and as the genus/species $C$. taurinus with 0.061 and.089 typicality, respectively. Once again, these results suggest that this specimen is most similar to an alcelaphine though atypical for the alcelaphine species in the reference database. Comparisons. The Malapa specimens were compared with Megalotragus sp. from Swartkrans Members 1-3, Kromdraai A, Sterkfontein Member 4, and Makapansgat; the characteristics of the Malapa specimens described above are consistent with Megalotragus sp. (Gentry and Gentry, 1978; Vrba, 1976; Brink, 2005). The Malapa specimens are not consistent with the traits of Connochaetes. Specifically, the $\mathrm{P}_{4}$ hypoconid in UW 88-1250 and UW 88-556 is hyper-robust compared to Connochaetes and does not have dental constriction of 

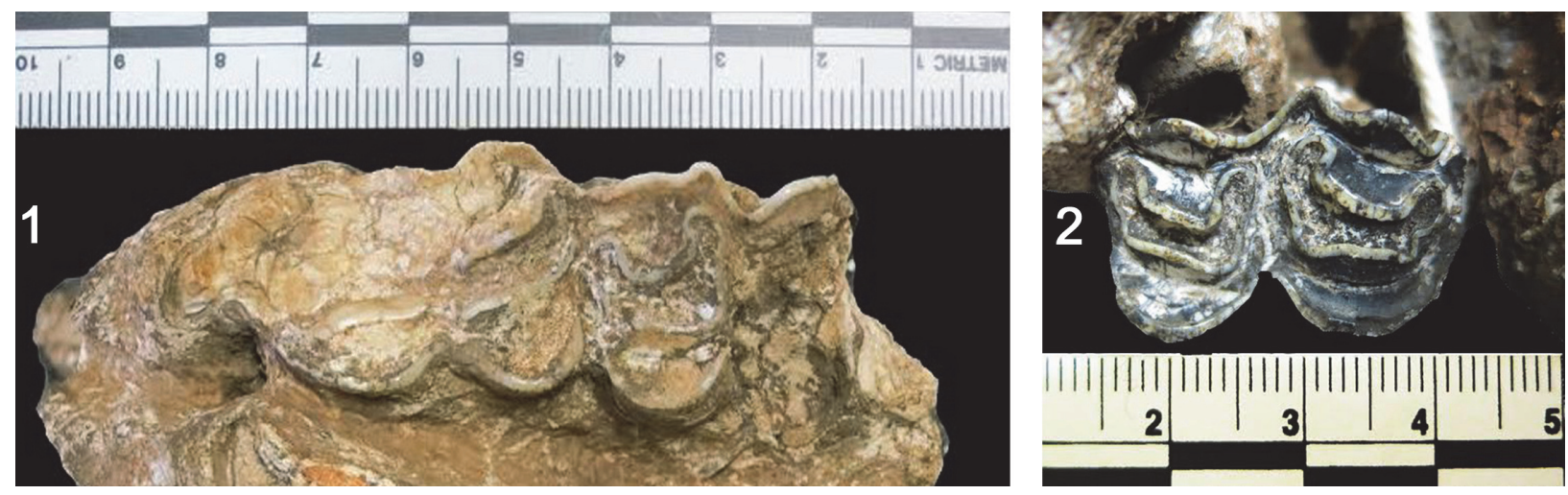

FIGURE 5. Malapa specimen UW 88-1299, right maxillary fragment with $\mathrm{M}^{2}$ and $\mathrm{M}^{3}$ (left). Malapa specimen UW 881205 , left maxillary fragment with $\mathrm{M}^{1}$ (right).

the $\mathrm{P}_{4}$ hypoconid as seen in Connochaetes (Brink, 2005). Tooth size was not a conclusive factor for establishing genus/species of the Megalotragus sp. Malapa teeth due to overlap in tooth size between Megalotragus and Connochaetes specimens (Table 5). Only the size of the $\mathrm{M}_{2}$ from UW 88-1251 falls outside of the range of Connochaetes $\mathrm{sp}$. and within the normal range of size variation for the Megalotragus sp.

Tribe ALCELAPHINI de Rochebrune, 1883 Alcelaphini gen. et sp. indet.
Material. UW 88-877 includes the anterior portion and diastema of a mandibular fragment of a bovid BSC III.

Description. The size, elongated diastema, and relatively straight morphology of UW 88-877 suggest this specimen belongs in the tribe Alcelaphini (Figure 8).

\section{Subfamily ANTILOPINAE Gray, 1821 Tribe ANTILOPINI Gray, 1821 Genus ANTIDORCAS Sundevall, 1847 Antidorcas recki Schwarz, 1932}

Material. UW 88-1298 is a right mandible with $\mathrm{P}_{4}$, $M_{1}, M_{2}$, and $M_{3}$ (Figure 9).

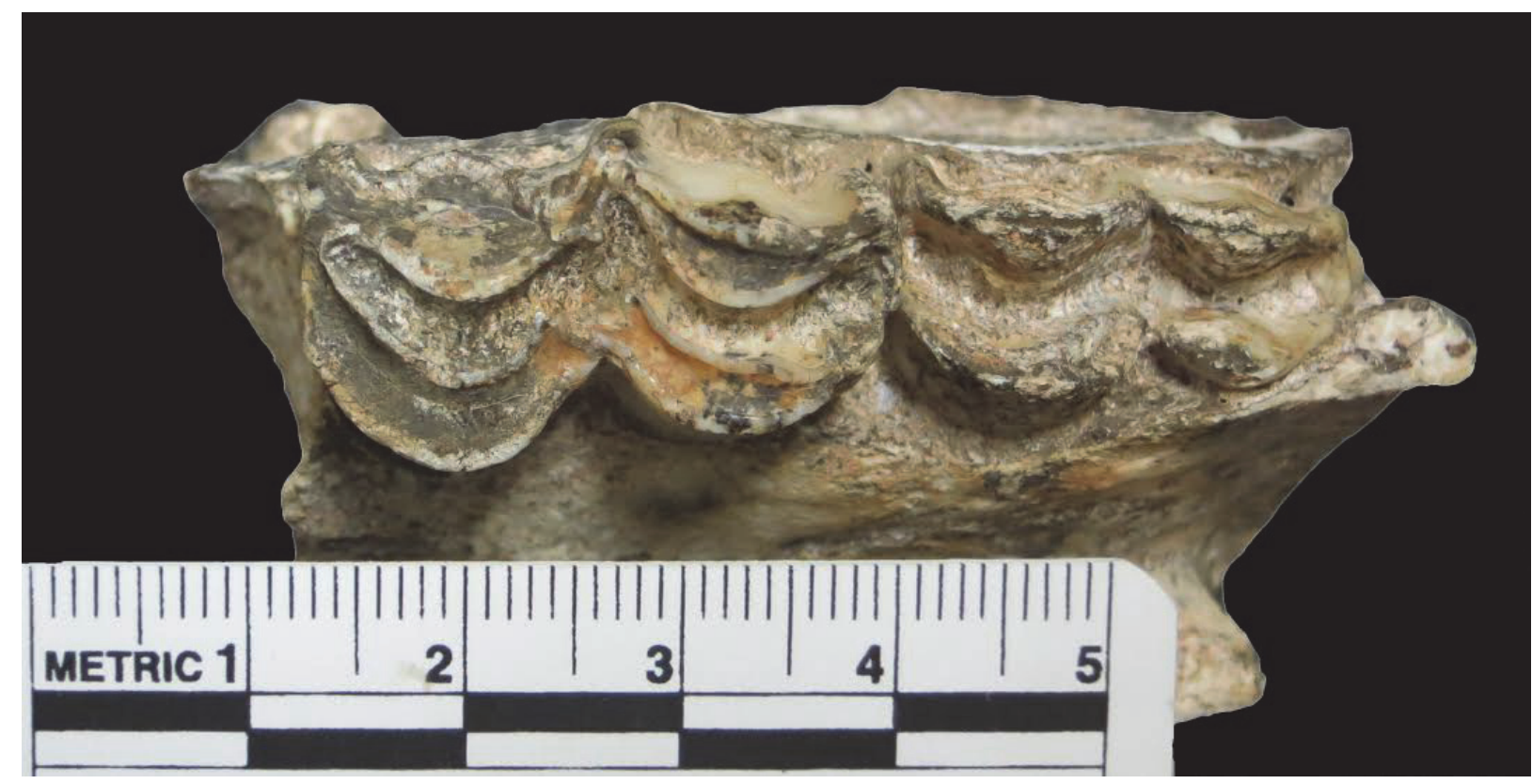

FIGURE 6. UW 88-746 maxilla with left $\mathrm{M}^{2}$ and $\mathrm{M}^{3}$. 

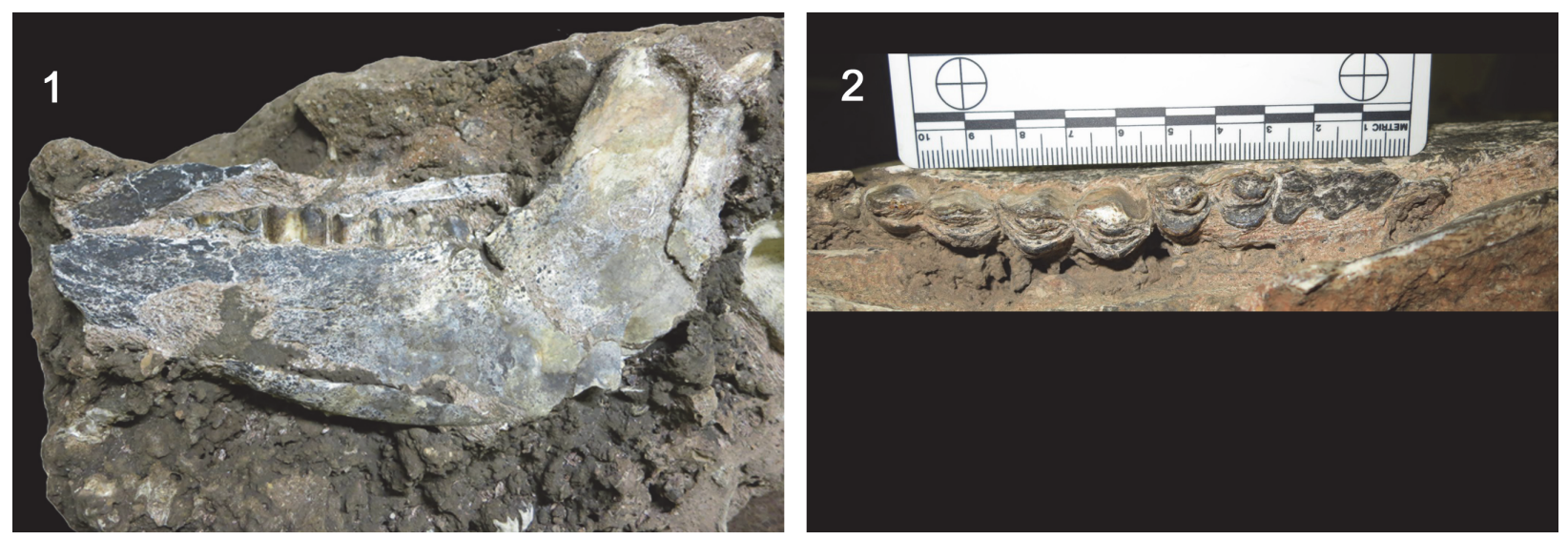

FIGURE 7. Lateral (left) and occlusal view (right) of UW 88-1251.

Description. The teeth of UW 88-1298 are heavily worn and have moderately hypsodont teeth. The mandible retains evidence of a $P_{2}$. The central cavities of the $M_{3}$, while nearly obliterated, are relatively straight. EFFA classified the $M_{1}$ and $M_{2}$ of UW 88-1298 to the tribe Antilopini with a 0.65 and 0.74 typicality probability, respectively, and to the genus/species Antidorcas marsupialis, the extant springbok, but at an extremely low probability $(<0.05)$ suggesting that these teeth have characteristics similar to extant springboks but are not consistent with $A$. marsupialis.

Comparisons. This specimen is consistent with the attribution to Antidorcas recki. According to
Vrba (1976), unbent central cavities and a straight mandibular lingual molar face are characteristics of A. recki. The teeth of UW 88-1298 are not extremely hypsodont as seen in $A$. bondi specimens from Swartkrans. Also, the retention of a $\mathrm{P}_{2}$ is atypical for $A$. marsupialis (Vrba, 1976). Finally, the buccal lophs are more v-shaped than $A$. marsupialis.

\section{Genus ANTIDORCAS Sundevall, 1847 ANTIDORCAS sp.}

Material. UW 88-869 is a right mandibular $\mathrm{M}_{1}$ (Figure 10) with morphology consistent with Antidorcas, including moderate hypsodonty and slightly

TABLE 5. Measurements of Malapa teeth compared with Megalotragus sp. and Connochates sp. fossils recovered from Swartkrans Member 1, Kromdraai A, Sterkfontein Member 4, and Makapansgat (Vrba, 1976; Reed, 1996). Due to sample size, mean and minimum and maximum sizes were not always able to be determined. Size was only able to aid in taxonomic designation for the $\mathrm{M}_{2}$.

\begin{tabular}{|c|c|c|c|c|c|c|c|c|c|c|c|}
\hline \multirow[b]{2}{*}{$\begin{array}{l}\text { Accession } \\
\text { Number }\end{array}$} & \multirow[b]{2}{*}{$\begin{array}{l}\text { Tooth } \\
\text { Type }\end{array}$} & \multirow[b]{2}{*}{$\begin{array}{c}\text { Tooth } \\
\text { Measurement } \\
(\mathrm{mm})\end{array}$} & \multicolumn{4}{|c|}{ Megalotragus } & \multicolumn{4}{|c|}{ Connochaetes } & \multirow[b]{2}{*}{$\begin{array}{c}\text { Designation } \\
\text { based on size }\end{array}$} \\
\hline & & & Mean & Min & Max & $\mathbf{n}$ & Mean & Min & Max & $\mathbf{n}$ & \\
\hline UW 88-1311 & $P^{4}$ & 16.1 & 16.5 & 16.5 & 16.5 & 1 & 18.1625 & 14.5 & 23.1 & 8 & Inconclusive \\
\hline UW 88-1205 & $\mathrm{M}^{1}$ & 27.34 & 24.4 & $\mathrm{~N} / \mathrm{A}$ & $\mathrm{N} / \mathrm{A}$ & 1 & 24.11 & 18.5 & 28.2 & 15 & Inconclusive \\
\hline UW 88-746 & $M^{2}$ & 28.31 & 27.15 & 24 & 30.3 & 2 & 27.5 & 23 & 32.1 & 21 & Inconclusive \\
\hline UW 88-556 & $\mathrm{P}_{4}$ & 19.74 & 15.5 & $\mathrm{~N} / \mathrm{A}$ & $\mathrm{N} / \mathrm{A}$ & 1 & 21.55 & 9 & 31.5 & 20 & Inconclusive \\
\hline UW 88-1250 & $\mathrm{P}_{4}$ & 19.01 & & & & & & & & & Inconclusive \\
\hline UW 88-1250 & $P_{3}$ & 13.73 & $\mathrm{~N} / \mathrm{A}$ & $\mathrm{N} / \mathrm{A}$ & $\mathrm{N} / \mathrm{A}$ & & & & & & Inconclusive \\
\hline UW 88-1250 & $\mathrm{M}_{1}$ & 22.22 & 20.5 & $\mathrm{~N} / \mathrm{A}$ & $\mathrm{N} / \mathrm{A}$ & 1 & 21 & 16.5 & 25 & 13 & Inconclusive \\
\hline UW 88-1251 & $M_{1}$ & 23.5 & & & & & & & & & Inconclusive \\
\hline UW 88-1251 & $\mathrm{M}_{2}$ & 29.66 & 32.825 & 28 & 35 & 6 & 24.865 & 22.5 & 28 & 20 & Megalotragus \\
\hline
\end{tabular}




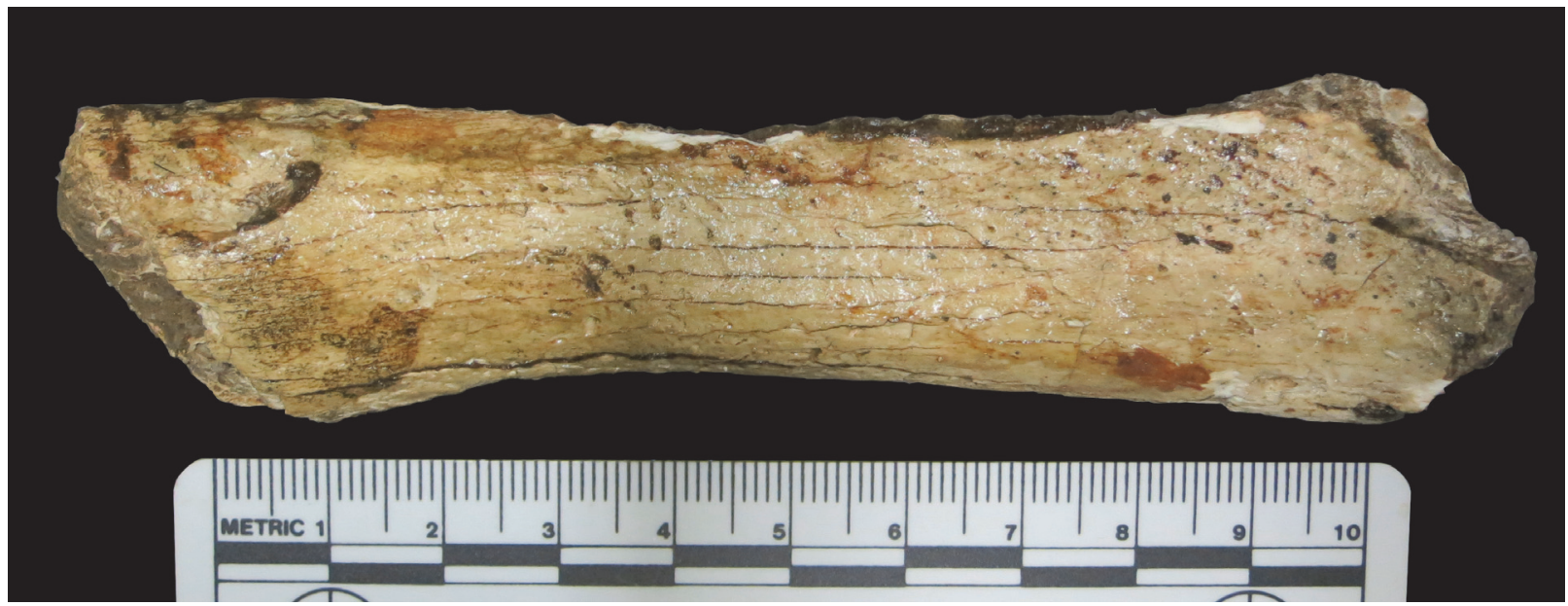

FIGURE 8. UW 88-877 Body Size Class III bovid mandible fragment.

pinched buccal mandibular molars. The specimen is not complete enough to perform EFFA and too worn to confidently classify it to species.

\section{Tribe ANTILOPINI Gray, 1821}

Antilopini gen. et sp. indet.

Material. Specimen UW 88-562 is a right maxillary fragment with $M^{1}$ and $M^{2}$ (Figure 11). The teeth are too incomplete to make a genus/species taxonomic diagnosis. While broken, the size and relative shape appear to overlap with multiple species in the subfamily Antilopinae.

Bovidae gen. et sp. indet.

Material. Cranial Specimens

UW 88-796 is a maxilla with right $\mathrm{P}^{3}, \mathrm{P}^{4}$, and $M^{1}$. The teeth are too heavily worn to identify them to the level of tribe with confidence, though the general morphology and lack of a basal pillar sug- gests this individual possibly belongs to the tribe Alcelaphini. UW 88-1314 is a partial mandible of a BSC II bovid consisting of the anterior portion with a broken incisor and the diastema of a mandible. A partial horn core, UW 88-555, was recovered from the site (Figure 12). The width of the base is 27.35 $\mathrm{mm}$ and the height is 37.33 . The horn core size identifies it as a bovid BSC II. UW 88-734 consists of a partial horn core of a BSC III bovid with a proximal width of $34.13 \mathrm{~mm}$ and height or $151.63 \mathrm{~mm}$ (Figure 13). The morphology of this specimen, including slight torsion and a transverse ridge, is not inconsistent with Megalotragus though the specimen is not well enough preserved for taxonomic identification.

Material. Postcranial Specimens

The Malapa postcranial assemblage is noteworthy due to the extraordinary preservation, exemplified by the numerous complete skeletal

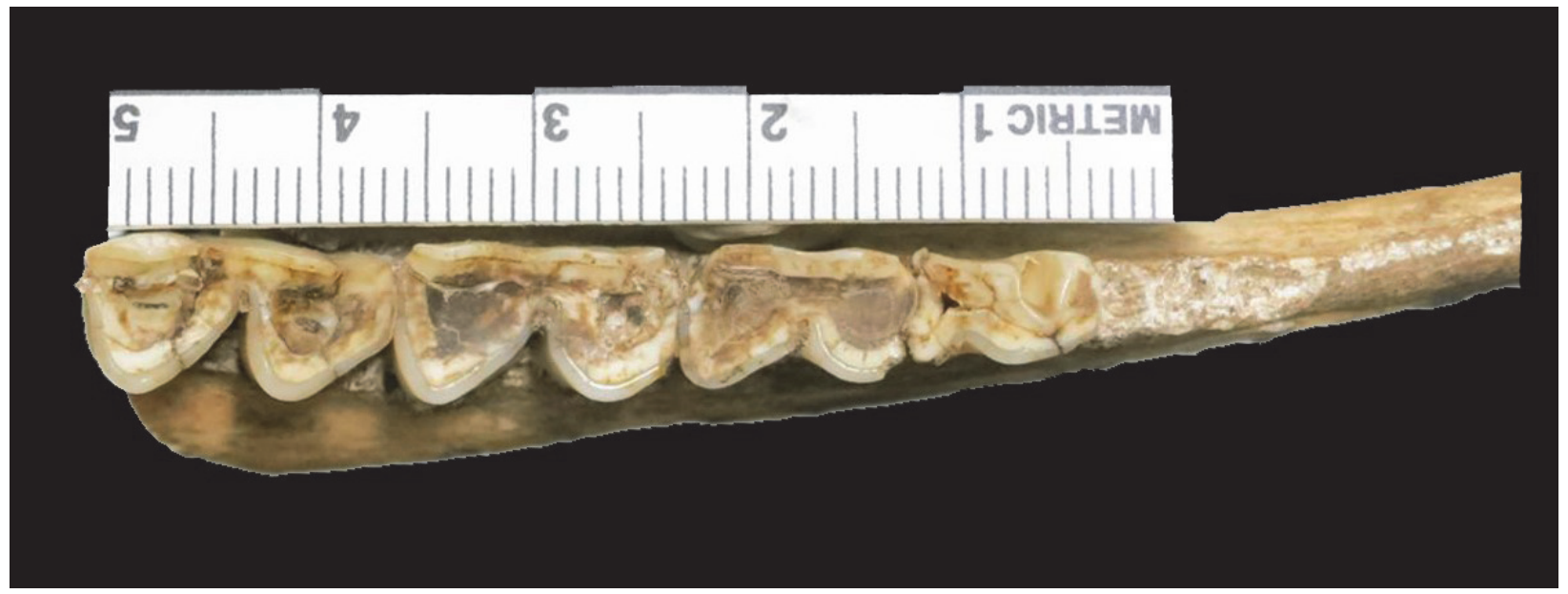

FIGURE 9. UW 88-1298 right Antidorcas recki adult mandible. 


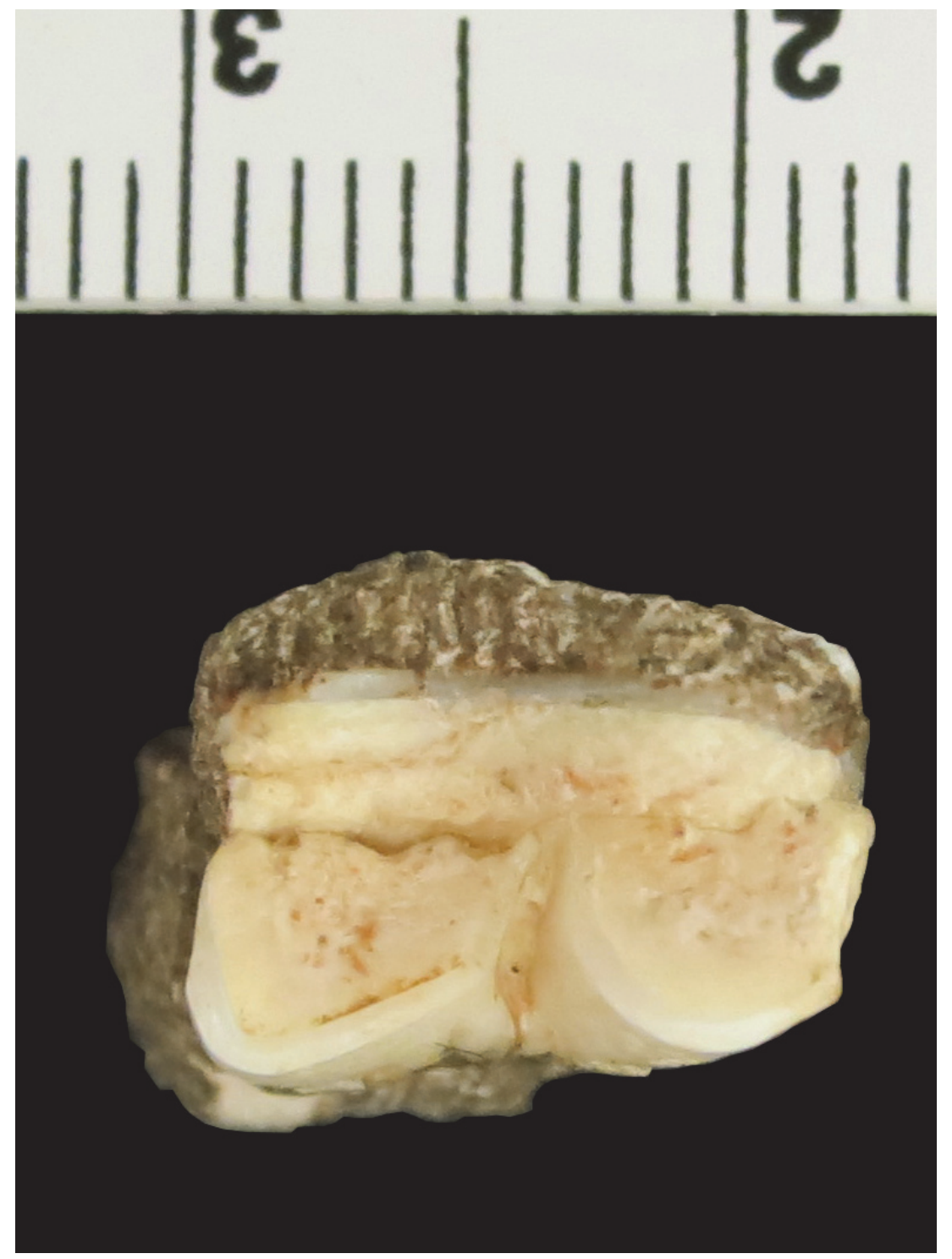

FIGURE 10. UW 88-869 right mandibular $\mathrm{M}_{1}$.

elements and partially articulated limbs. This preservation contrasts with the long bone fragments more commonly seen at sites such as Swartkrans and Kromdraai. The best example of this postcranial preservation is seen in Malapa Block 848 (Figure 13). This Block consists of portions of articulated/associated limbs including a diaphysis and epiphysis of a left femur (UW 88-1181), right and left complete tibiae (UW 88-1223a, b), right proximal metatarsal (UW 88-1224), complete astragalus (UW 88-1225), complete naviculocuboid (UW 88-1226), and two complete distal phalanges (UW 88-1221a, b) (Figure 13). While not in articulation or encased in the same rock, a complementary right femur (UW 88-748) matching the size and approximate age of the one in Block
848 was recovered. UW 88-748 consists of a distal epiphysis, diaphysis, and proximal epiphysis that refit making a complete specimen $(210.3 \mathrm{~mm})$. The incomplete left femur, UW 88-1181, measures 203 $\mathrm{mm}$; estimates of a complete left femur overlap with the right femur, UW 88-748. The specimens in Block 848 and UW 88-748 represent an adult based on epiphyseal fusion. The estimated age for the individual in Block 848 is $12-18$ months due to the fact that the proximal tibiae are fused while UW 88-748 is at least 10-18 months (Davis, 1980). These fossils are consistent in size with a BSC II. According to Swanepoel and Steyn's (2011) study on robusticity of Bovidae hindlimbs, a total femoral length of approximately $210 \mathrm{~mm}$ from UW 88-748 and UW 88-1181 (estimated) overlaps most closely 


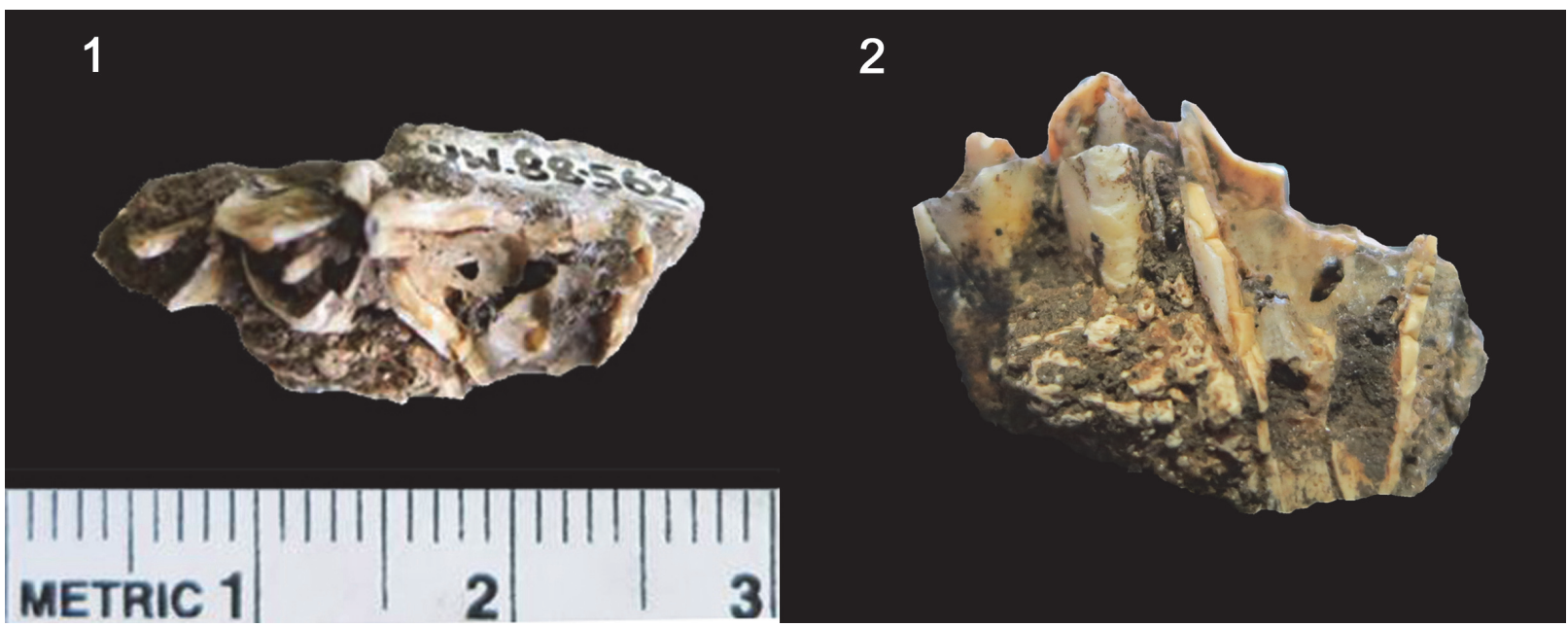

FIGURE 11. UW 88-562 BSC I bovid, Subfamily Antilopinae.

with the femora of Antidorcas marsupialis (204.2 \pm 14.9 ) and Redunca fulvorufula (206.0 \pm 7.3 ). The total tibial length of $258.5 \mathrm{~mm}$ suggests that this individual's body mass overlaps in range with Antidorcas marsupialis (258.1 \pm 19.1$)$, Redunca fulvorufula (254.0 \pm 7.4$)$, and Tragelaphus scriptus (249.9 \pm 13.8$)$ (Swanepoel and Steyn, 2011).

Block 051 contains a complete right humerus (209 mm), UW 88-1184, in articulation with a right, proximal and diaphysis shaft of a radius, UW 881213. Both of the elements are adults based on the epiphyseal fusion, 12-18 months old, and are BSC III (Davis, 1980).

Three articulated cervical vertebrae were recovered from Malapa. UW 88-720, 88-721, and 88-722 represent an adult, BSC II individual (Figure 14). Block 081 also contains articulated vertebrae. UW 88-1235 from Block 081 includes two adult thoracic vertebrae from BSC III. An articulated BSC III proximal humerus and glenoid cavity of a scapula were also found in articulation. These specimens are adults, $12-18$ months based on the fusion of the proximal humerus (Davis, 1980).

While the sample size is small, the skeletal part representation illustrates that the bovid postcranial remains are comprehensive; essentially the entire bovid skeleton is represented in some degree at the site (Table 6). While minimal, this evidence supports the hypothesis that complete bovid individuals accumulated in the cave.

\section{Phytolith Results}

Unfortunately, very few phytolith fragments preserved on the Malapa bovid teeth and the ones that did were of very poor quality. The most common fragments are indeterminate, of no particular shape, and cannot be related to any phytolith morphotype. The second most common fragments are more or less geometric in shape (square, triangle, rectangle, etc.). These remains are probably siliceous but not related to any phytoliths. The samples frequently contained brown amorphous "blobs," which may be a chemical residue. Some
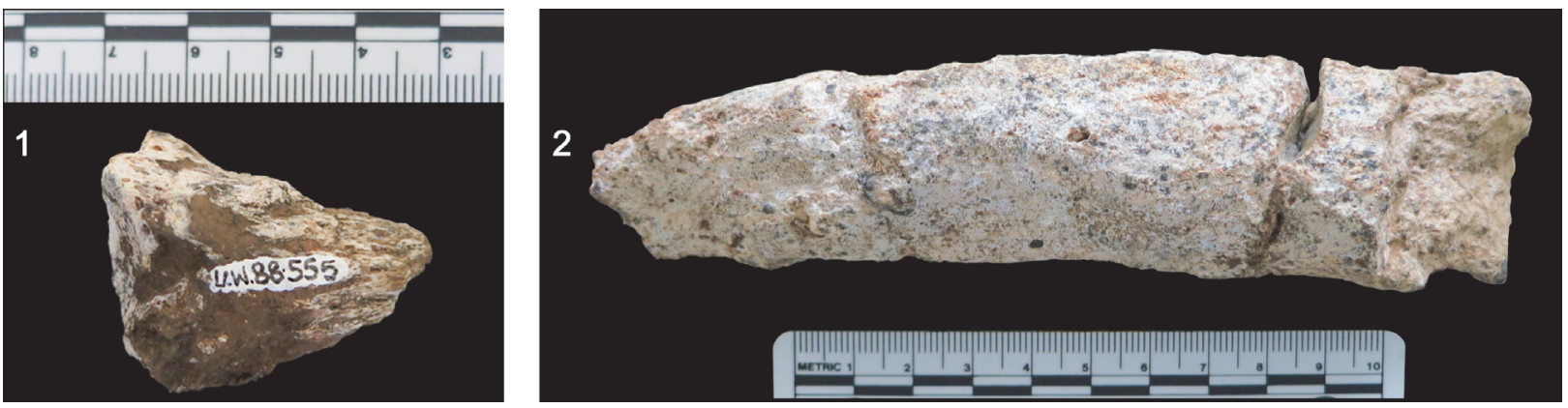

FIGURE 12. UW 88-555 horn core fragment of BSC II (left). UW 88-734 partial horn core of a BSC III (right). 


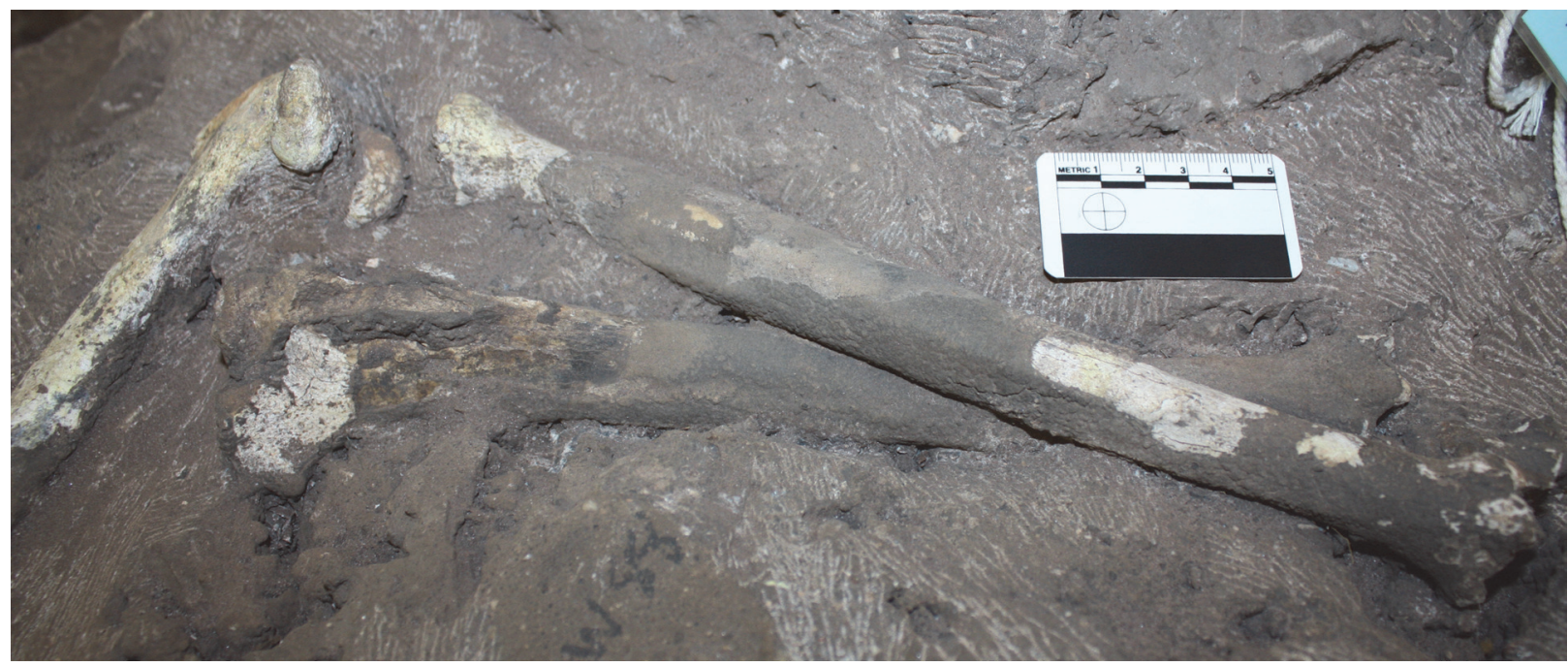

FIGURE 13. Block 848 bovid BSC II in situ with femur and tibiae in articulation. Associated right metatarsal, astragalus, naviculocuboid, and distal phalanx are also in the Block.

samples have fragments of hexagonal mesh, which have been interpreted as insect eye facets. Fungal hyphae also occur but their source is unknown. A few phytoliths were identified from three bovid specimens. Grass inflorescences, woody dicot and tracheid morphotypes were recovered from Megalotragus sp. specimens, UW 88746 and UW 88-1205, respectively. These results suggest Megalotragus sp. could have been a $\mathrm{C}_{4}$ grazer with some browse in its diet. Makapania broomi (UW 88-929) exhibit two very poorly preserved saddle morphotypes, which imply a diet that includes $\mathrm{C}_{4}$ grasses.

\section{Mesowear Results}

Due to the preservation of the fossils and small sample size, a formal analysis of the mesowear could not be performed. Larger sample sizes can illustrate differences in the proportions of occlusal relief and cusp shapes that can be used to infer paleodiets. However, it is still informative to discuss the wear patterns of even single specimens that retain indications of occlusal relief and cusp shape. This data, coupled with other lines of research, can help identify the Malapa bovids and their diet.

The $\mathrm{M}_{2}$ and $\mathrm{M}_{3}$ of $T$. scriptus (UW 88-518 and UW 88-519) have high relief (Figure 15). While cusp damage makes identification of the outline difficult, the tips of the $M_{2}$ and $M_{3}$ appear sharp. This morphology coupled with taxonomic uniformitarianism suggests that $T$. scriptus was likely a browser or, possibly, a mixed feeder at the browsing end of the spectrum. In addition, the Spon- heimer et al. (1999) isotope study found that $T$. scriptus was a browser.

The $\mathrm{M}^{1}$ of $M$. broomi (UW 88-929) is fairly worn for scoring, and the cusps of the $\mathrm{M}^{2}$ are broken. Nevertheless, the relief appears high, and the cusp tip is rounded in both the upper and the lower molars. Based on mesowear, the specimen UW 88-929 was likely a mixed feeder or perhaps a fresh grass grazer. These results support the phytolith results above and Sponheimer et al. (1999) which suggest $M$. broomi was a mixed feeder that prefers grass.

The $\mathrm{M}^{2}$ of Megalotragus (UW 88-746) is also broken but the specimen exhibits high relief and rounded cusp tips. This morphotype possibly suggests a mixed feeder preferring grass. The Megalotragus (UW 88-1205) $\mathrm{M}^{1}$ has moderate wear and discernible morphology. The relief is high and the cusp tip is rounded. The analyses suggest that UW 88-1205 was possibly a mixed feeder though the overall appearance and weak facet development provides a stronger indication that it was a grazer. Both the $\mathrm{M}_{1}$ and $\mathrm{M}_{2}$ of Megalotragus (UW 88-1251) show high relief and rounded cusp tips. The $M_{3}$ is unworn. This morphology suggests a mixed feeder towards the grazing end of the spectrum. These results correlate with Brink and Lee-Thorp (1992), which suggests Megalotragus was a grazer.

\section{Taphonomy Results}

Surface modification on the Malapa bovid limb bones includes cortical peeling, cracking, crushing, and erosion (Figures 16, 17). A significant portion $(n=44), 86 \%$, of the $51 \mathrm{limb}$ fragments demonstrate 
TABLE 6. Skeletal part representation of Malapa bovid postcrania divided up by Body Size Class (BSC) (Number of Identified Specimens/Minimum Number of Elements/Minimum Number of Individuals).

\begin{tabular}{|c|c|c|c|c|c|c|c|}
\hline & BSI & BSII & BSIII & & & & \\
\hline Humerus, complete & & $1 / 1 / 1$ & & Metapodial & & & \\
\hline Proximal humerus & & $1 / 1 / 1$ & $2 / 2 / 1$ & Distal metatarsal & & $1 / 1 / 1$ & $2 / 2 / 1$ \\
\hline Distal humerus & & $1 / 1 / 1$ & $3 / 2 / 1$ & Scapula & & $8 / 3 / 3$ & $2 / 2 / 2$ \\
\hline Femur, complete & & $1 / 1 / 1$ & & Atlas & & $1 / 1 / 1$ & \\
\hline Proximal femur & & $2 / 2 / 2$ & & Axis & & $1 / 1 / 1$ & \\
\hline Distal femur & & $4 / 3 / 2$ & $2 / 1 / 1$ & Cervical vertebra & & $7 / 7 / 2$ & $1 / 1 / 1$ \\
\hline Tibia, complete & & $2 / 2 / 1$ & & Thoracic vertebra & & $6 / 6 / 2$ & $5 / 5 / 2$ \\
\hline Proximal tibia & & $2 / 2 / 2$ & $1 / 1 / 1$ & Lumbar vertebra & & $8 / 5 / 2$ & \\
\hline Shaft tibia & & $1 / 1 / 1$ & $1 / 1 / 1$ & Caudal vertebra & & & $1 / 1 / 1$ \\
\hline Distal tibia & & $2 / 2 / 1$ & & Stenebra & & $1 / 1 / 1$ & \\
\hline Radius & & & & Pelvis & & $1 / 1 / 1$ & \\
\hline Proximal radius & & $1 / 1 / 1$ & & Ribs & & $32 / 5 / 1$ & $10 / 4 / 1$ \\
\hline Shaft radius & & $1 / 1 / 1$ & $1 / 1 / 1$ & Sacrum & & $3 / 2 / 2$ & \\
\hline Distal radius & & $1 / 1 / 1$ & $1 / 1 / 1$ & Proximal phalanx & & $4 / 3 / 1$ & $10 / 10 / 3$ \\
\hline Ulna & & & & Intermediate phalanx & $1 / 1 / 1$ & $4 / 4 / 2$ & $7 / 7 / 2$ \\
\hline Proximal ulna & & & $3 / 3 / 2$ & Distal phalanx & $2 / 2 / 1$ & $2 / 2 / 1$ & \\
\hline Shaft ulna & & $1 / 1 / 1$ & & Accessory carpal & & $1 / 1 / 1$ & \\
\hline Distal ulna & & & $1 / 1 / 1$ & Astragalus & & $3 / 3 / 2$ & $1 / 1 / 1$ \\
\hline Metacarpal, complete & & & $6 / 2 / 1$ & Calcaneous & & $4 / 3 / 3$ & $2 / 2 / 2$ \\
\hline Proximal metacarpal & & $3 / 3 / 2$ & & Internal cuneiform & & & $1 / 1 / 1$ \\
\hline Shaft metacarpal & & & $1 / 1 / 1$ & Cuneiform & & $1 / 1 / 1$ & \\
\hline Distal metacarpal & & $2 / 2 / 1$ & & Lateral malleolus & & & $1 / 1 / 1$ \\
\hline Metatarsal & & & & Magnum & & $2 / 2 / 1$ & \\
\hline Proximal metatarsal & & $1 / 1 / 1$ & $1 / 1 / 1$ & Naviculo-cuboid & & $2 / 2 / 1$ & $1 / 1 / 1$ \\
\hline Shaft metatarsal & $1 / 1 / 1$ & & $4 / 2 / 1$ & Scaphoid & & $1 / 1 / 1$ & \\
\hline Distal metatarsal & & $1 / 1 / 1$ & $1 / 1 / 1$ & Unciform & $1 / 1 / 1$ & $1 / 1 / 1$ & \\
\hline & & & & Sesamoid & & & $7 / 7 / 2$ \\
\hline
\end{tabular}

signs of cracking while $\sim 24 \%$ of the assemblage reveal signs of being crushed $(n=12)$. Twenty percent of the assemblage exhibit cortical peeling. According to Behrensmeyer (1978), longitudinal cracking in long bones is indicative of Stage 1 weathering, while cortical peeling and cracking denotes Stage 2 weathering (Figure 16). Therefore, a majority of the assemblage was in Stage 2 weathering during fossilization. None of the bovid bones demonstrated any signs of weathering beyond Stage 2, as defined by Behrensmeyer (1978).

The breakage patterns of the limb bones include right, oblique, and intermediate fracture

angles; each make up approximately one-third of the assemblage, $31 \%, 33 \%$, and $36 \%$, respectively. While approximately $32 \%$ of the long bone shaft fragments have transverse outlines, 34\% have curved and $34 \%$ have intermediate fracture outlines in the morphology. Approximately $80 \%$ $(n=36)$ of the long bones have a complete shaft circumference in at least a portion of the bone (Figure 18). A majority, $71 \%$, of the assemblage has $1 / 2$ or less of its original shaft length (Figure 19).

Age estimates for the Malapa specimens were determined in order to identify if the assemblage favors old or young individuals. The craniodental remains include young specimens with deciduous 

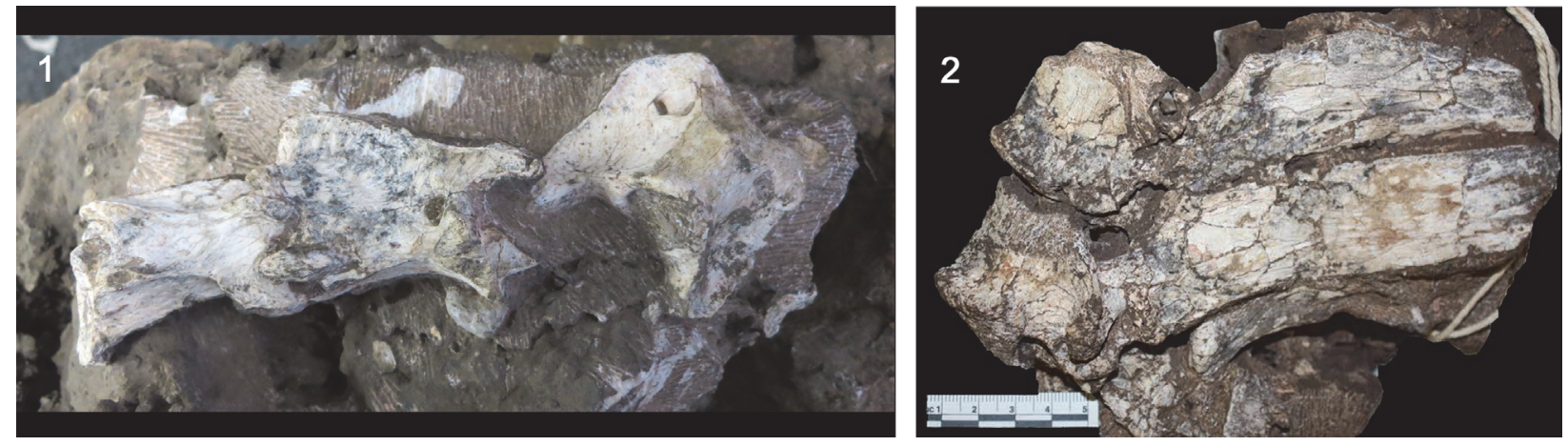

FIGURE 14. Malapa blocks with articulated cervical (left) and thoracic (right) vertebrae.

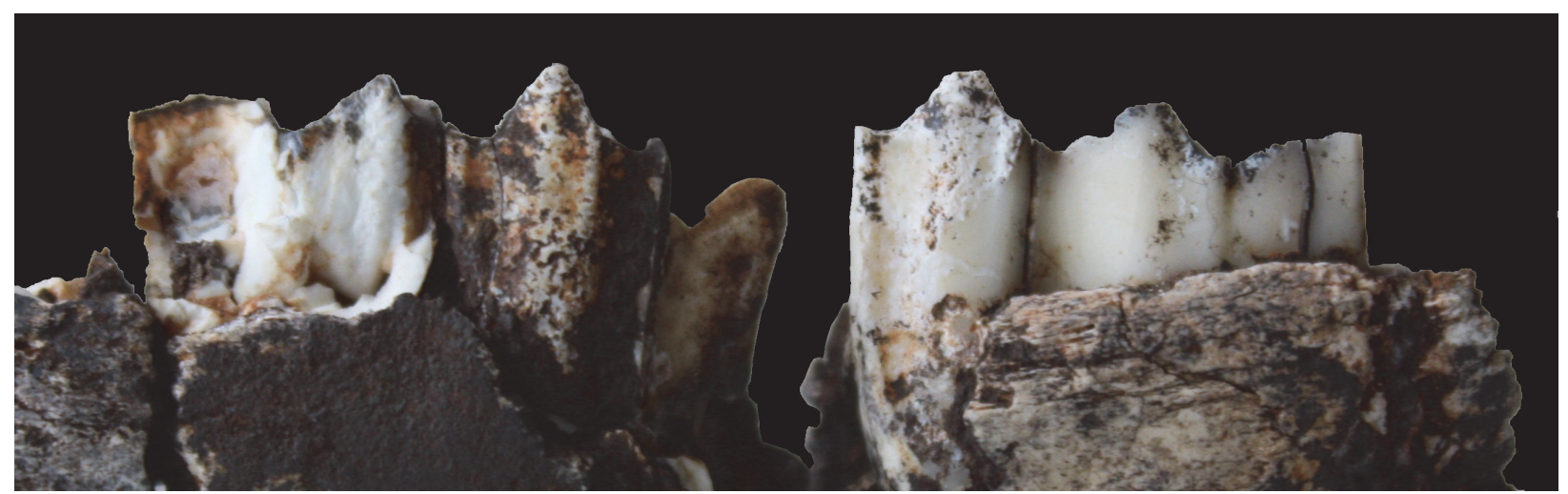

FIGURE 15. Lingual view of Malapa UW 88-518 and UW 88-519 demonstrating high occlusal relief and sharp cusps.
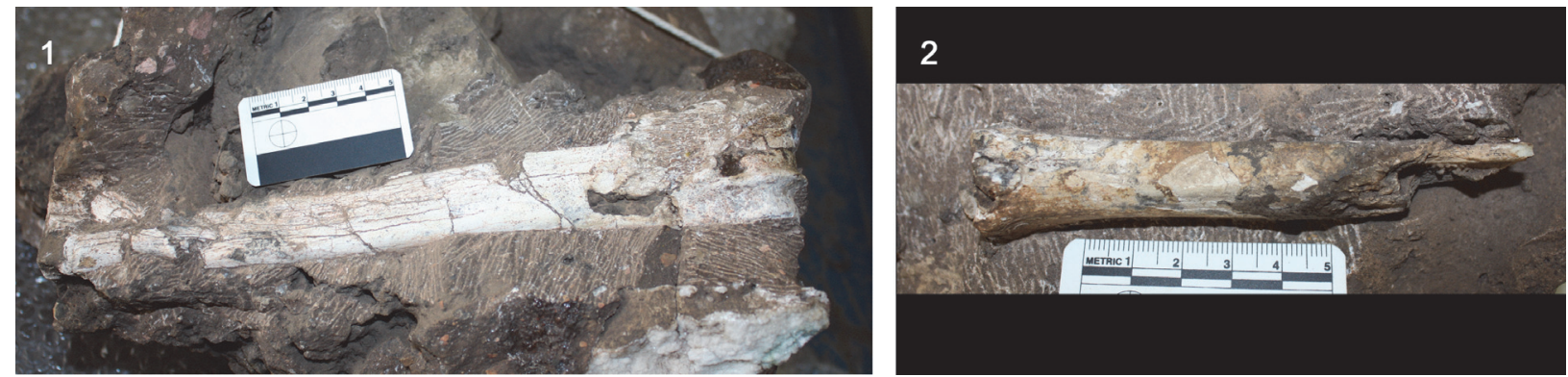

FIGURE 16. Metapodial (left), UW 88-1247, demonstrating cracking and longitudinal fractures typical of Behrensmeyer (1975) Stage 1 weathering and diagenetic processes. UW 88-1224, (right) metatarsal exhibits longitudinal fractures, cracking, and cortical peeling.

and erupting teeth (e.g., UW 88-1251, UW 88746), older individuals with fully erupted teeth (e.g., UW 88-929), and older, worn down teeth (e.g., UW 88-796, UW 88-1298). Age estimates for the Malapa Megalotragus sp. specimens are listed in Table 7 and range from 6-33 months. The ages are based on the occlusal rates of Connochaetes taurinus since eruptions rates for Megalotragus do not exist (Talbot and Talbot, 1963). The postcranial elements range in age estimates from 10-18 months.
Therefore, the ages of the bovids do not appear to follow any age patterns.

\section{DISCUSSION}

The faunal list presented in this paper is different than Dirks et al. (2010) and Val et al. (2015) based on a reanalysis of the Malapa bovid data. It is not possible to highlight exactly which identifications differ from Dirks et al. (2010) due to the fact that they do not provide accession numbers for their identifications. Table 8 illustrates the differ- 


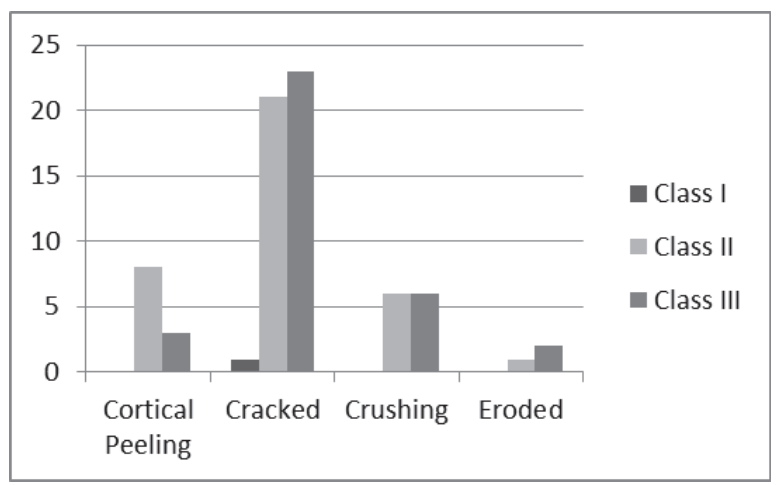

FIGURE 17. Types of surface modification identified on Malapa bovid limb bones and number of specimens with that modification.

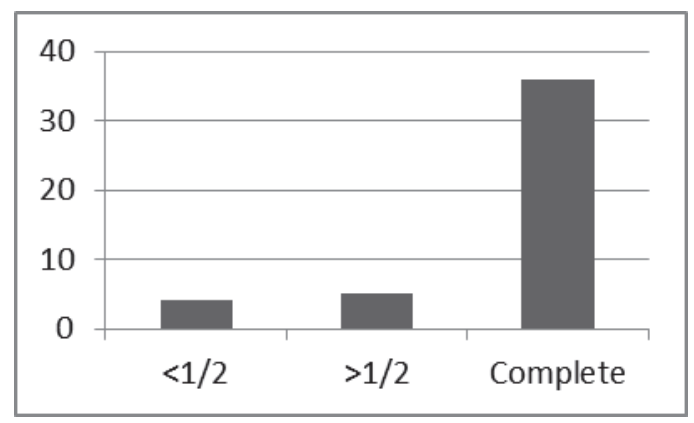

FIGURE 18. Results of the shaft circumference completeness in Malapa bovid limb bones.

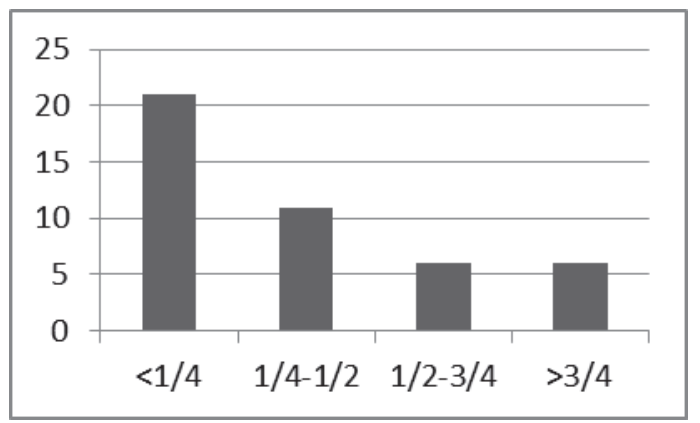

FIGURE 19. Results of the shaft fragmentation in Malapa bovid limb bones.

ences between those suggested in this paper and those in Val et al. (2015). It is important to note that the purpose of Dirks et al. (2010) and Val et al. (2015) was not explicitly to identify the bovids. Dirks et al. (2010) concentrated on the geological setting while Val et al. (2015) focused on the taphonomy of all of the vertebrate fauna. In addition, this study assessed a larger bovid sample. As more material is prepared out of the sediments and
TABLE 7. Estimated ages of Megalotragus sp. specimens from Malapa based on occlusion rates from Connochaetes taurinus (Talbot and Talbot, 1963).

\begin{tabular}{cc}
\hline $\begin{array}{c}\text { Accession } \\
\text { Number }\end{array}$ & $\begin{array}{c}\text { Estimated Age of } \\
\text { Specimen } \\
\text { (months) }\end{array}$ \\
\hline UW 88-556 & $<30-33$ \\
UW 88-746 & $30-33$ \\
UW 88-1205 & $\sim 6$ \\
UW 88-1249 & $26-28+$ \\
UW 88-1250 & $37-40+$ \\
UW 88-1251 & $26-28$ \\
UW 88-1299 & $30-33+$ \\
UW 88-1311 & $30-33+$ \\
\hline
\end{tabular}

excavations continue, it is likely that the number of individual specimens and species will increase.

The Malapa bovid taxonomic list is consistent with other South African sites in the Pleistocene despite the fact that comparatively Malapa comprises a significantly smaller sample size than other sites (e.g., Vrba, 1976; Reed, 1996; de Ruiter, 2003; de Ruiter et al., 2009); however, none of the sites in the near vicinity contain identical taxonomic representation meaning this combination of species unknown from any nearby site. In particular, it is possible that the existence of Makapania broomi varies in the area. Makapansgat Member 3 and Sterkfontein M5A, the STW 53 Infill, contain Makapania broomi while Makapania cf. broomi was recovered from Sterkfontein M4 (Vrba, 1976; Reed, 1996; Herries et al., 2009; Reynolds and Kibii, 2011). Only Makapania sp. was identified from SK Hanging Remnant (SKHR) and Gladysvale (GVED) (Lacruz et al., 2002; de Ruiter, 2003). Vrba (1976) recognizes cf. Makapania sp. from Swartkrans M1 and Adams (2012) identifies bovids as possibly representing cf. Makapania sp. at Haasgat ex situ HGD. The different taxonomic designations of these specimens either represent the possibility of two or more morphs in the Subfamily Caprinae in the Plio-Pleistocene (Brink, 1999; Adams, 2012), or the possibility that at least some of these specimens are actually variations of the same genus and species. Interobserver error can result from a variety of factors including varied preservation of the fossils, an analyst's experience, and an analyst's access to comparative materials (see Brophy, 2011). Regardless of the published taxonomic des- 
TABLE 8. Differences in identifications between this paper and identifications listed in Val et al. (2015).

\begin{tabular}{ccl}
\hline $\begin{array}{c}\text { Accession } \\
\text { Number }\end{array}$ & Suggested Identifications & \multicolumn{1}{c}{ Val et al., (2015) } \\
\hline $88-518$ & Tragelaphus scriptus & Tragelaphus \\
$88-519$ & Tragelaphus scriptus & Tragelaphus \\
$88-555$ & Bovidae gen. et sp. indet. & Unknown Bovid II \\
$88-556$ & Megalotragus sp. & Bovid \\
$88-562$ & Antilopini gen. et sp. indet. & Tragelaphini \\
$88-734$ & Bovidae gen. et sp. indet. & Unknown Bovid III \\
$88-746$ & Megalotragus sp. & Alcelaphini Bovid III \\
$88-796$ & Bovidae gen. et sp. indet. & Unknown Bovid III \\
$88-797$ & Makapania broomi & Unknown Bovid III \\
$88-869$ & Antidorcas sp. & not in paper \\
$88-877$ & Alcelaphini gen. et sp. indet. & Connchaetes \\
$88-929$ & Makapania broomi & Tragelaphus \\
$88-1015$ & Tragelaphus scriptus & Unknown Bovid II \\
$88-1205$ & Megalotragus sp. & Alcelaphini Bovid III \\
$88-1249$ & Megalotragus sp. & not in paper \\
$88-1250$ & Megalotragus sp. & not in paper \\
$88-1251$ & Megalotragus sp. & not in paper \\
$88-1298$ & Antidorcas recki & not in paper \\
$88-1299$ & Megalotragus sp. & not in paper \\
$88-1311$ & negalotragus sp. & \\
$88-1314$ & not in paper \\
\hline & &
\end{tabular}

ignations, Gentry (1970) states that this species was likely more widespread than the evidence suggested at the time. The recovery of Makapania broomi at Malapa supports Gentry's (1970) claim.

The Malapa bovid bushbuck specimens are conservatively identified to $T$. scriptus due to the fact that the morphology of the Malapa specimens overlaps with $T$. scriptus and the lack of characteristics differentiating $T$. pricei from $T$. scriptus. Tragelaphus pricei was first named Cephalophus pricei from Makapansgat with a mandible holotype (M18) and a horn corn paratype (M 478) (Wells and Cooke, 1956). M 478 was later reclassified as a Neotragini (Gentry, 1985). Wells and Cooke (1956) described the dentition of the species as having lower crowns (than gazelles), somewhat oblique lateral lobes, well defined internal ribs, and $\mathrm{P}_{4}$ paraconid-metaconid fusion. Gentry and Gentry (1978) and Gentry (1985) reclassified Cephalophus pricei as a tragelaphine due to the small size of the premolar row compared to the molar row, $\mathrm{P}_{4}$ paraconid-metaconid fusion, small $\mathrm{P}_{2}$ relative to the $P_{3}$ and $P_{4}$, and weakly rounded outbow- ings of the medial walls of the mandibular molars. Gentry (1985) further states that the size of the mandible suggests the animal would be approximately the size of an extant bushbuck. This definition thus overlaps with the characteristics of $T$. scriptus. Tragelaphus scriptus is defined as having brachydont teeth, basal pillars small or absent on lower molars, simple central cavities, narrowly pointed lateral lobes, long premolar rows, large $\mathrm{P}_{2} \mathrm{~s}$, shallow mandibular body, and common $\mathrm{P}_{4}$ paraconid-metaconid fusion (Gentry, 1985; Reed, 1996). Moreover, when Sponheimer et al. (1999) assessed the lower premolar row/lower molar row (PMR), the aforementioned MD/MR, the depth of the diastema at $P_{2}$ /lower molar row (DD/MR), and the unworn height of the $M_{3}$ /width of $M_{3}(H I)$, the two species overlapped within one standard deviation for every index except the PMR, which was within two standard deviations. In addition, according to Moodley and Bruford (2007), T. scriptus existed in southern Africa by 3 m.y.a.; therefore, the presence of this extant tragelaphine at 1.977 m.y.a. would not be unexpected. Therefore, the 
morphology UW 88-518, UW 88-519, and UW 881015 is consistent with a conservative identification of $T$. scriptus. It is important to note that this leaves Makapansgat as the only site with $T$. pricei in South Africa.

T. scriptus has been recovered from SK Member 2, which dates to 1.65-1.07 m.y.a., and at Makapansgat Member 5 (Reed, 1996; de Ruiter, 2003; Herries, et al., 2009). Tragelaphus cf. scriptus existed at Coopers D (1.9-1.5 m.y.a.), Kromdraai A ( 1.5 m.y.a.), and Sterkfontein Dump 16 (Vrba 1974, 1976; White and Harris, 1977; de Ruiter et al., 2009; Herries et al., 2009). Tragelaphus scriptus was identified at Intervals 4 and 5 of Konso Formation, Ethiopia dating to 1.43 and 1.33 m.y.a., respectively (Suwa et al., 2003). From the Turkana Basin in Kenya, Tragelaphus scriptus was recovered from Lower and Middle Lomekwi (3.362.94 m.y.a.), Upper Lomekwi + Lokalalei (2.94-2.35 m.y.a.), and Kaitio (1.88- 1.6 m.y.a.) (Fernández and Vrba, 2006). The existence of $T$. scriptus at 1.97 would be a somewhat early appearance date for South Africa but not inconsistent with its identification at other nearby sites.

The identification of $A$. recki at Malapa contributes to the understanding of the antilopine lineage. Hendey (1974) suggests that $A$. recki is ancestral to $A$. marsupialis/australis. de Ruiter (2003) illustrates how this could be problematic due to the coexistence of $A$. recki and $A$. marsupialis/australis in Members 2 and 3 of Swartkrans. This ancestor-descendant relationship is possible if A. marsupialis/australis evolved from $A$. recki early in the lineage (de Ruiter, 2003). The existence of A. recki at Malapa (1.977 m.y.a.), Kromdraai A (1.9-1.5 m.y.a.), and Kromdraai B (2.11-1.65 m.y.a.), sites older than Members 2 and 3 of Swartkrans, provides support for this suggested ancestor-descendant relationship (Vrba, 1995; de Ruiter, 2003; Herries et al., 2009; Dirks et al., 2010).

EFFA proved to be a useful tool for tribe and species identification of bovid teeth. Unfortunately, analyses of the phytoliths and mesowear of the bovid dental remains do not inform much on either the taxonomic designation or feeding ecology of the bovids. Due to the lack of preservation of dental calculus, the phytoliths did not preserve well enough or a large enough number to offer meaningful interpretations of the diet. In addition, the mesowear results are considered provisional due to the low minimum number of individuals of each bovid.

The small sample size of Malapa makes it difficult to discuss broad scale environmental trends.
Only a preliminary assessment of the paleoenvironment can be made based solely on the bovids. The bovid fauna list includes Megalotragus sp. whose diet includes $\mathrm{C}_{4}$ grasses. Megalotragus sp. is the most abundant bovid species found at the site. Makapania broomi, as a mixed feeder preferring grass, also indicates an abundance of grasslands with some available browse. The extinct springbok, A. recki, according to Luyt and LeeThorp (2003) and van de Merwe et al. (2003), is a browser and likely preferred a more closed environment with trees and shrubs than the extant $A$. marsupialis. Tragelaphus scriptus is a strict browser and indicates that a habitat of bushland and thicket was in the vicinity (Reed, 1996). Tragelaphus scriptus tends to live near water (Estes, 1992). This preliminary reconstruction suggests that Malapa was similar to nearby homininbearing caves in the presence of substantial grasslands, but also reveals a more wooded and better watered component than is typically recorded elsewhere in the area (de Ruiter et al., 2008).

While there is some debate about how much weathering occurs on bones deposited in subterranean contexts, a majority of the bovid limb bones demonstrate characteristics typical of subaerial weathering including cortical peeling, cracking, and erosion. No evidence exists for a biotic accumulating agent. No carnivore tooth marks, gnawing, or percussion marks were found on any of the bones. An analysis investigating surface modification of the entire Malapa sample using a multi-focus microscope revealed that invertebrates and microbes were the principal biotic agents responsible for bone surface modification (Val et al., 2015).

The breakage patterns of the bovid limb bones indicate that the assemblage does not explicitly fit into a particular category for deposition. Specifically, the fracture angles and outlines represent potentially peri and postmortem fractures though, as explained above, significant overlap exists in morphologies resulting from peri and postmortem fractures. The bovid remains demonstrate few taphonomic marks that explicitly and exclusively indicate perimortem trauma. Only approximately $10 \%$ of the assemblage exhibits trauma, which would be consistent with a fall or impact. While the hominin skeletons demonstrate signs of active resistance to an impact, most of the observed hominin fractures are post depositional (L'Abbé et al., 2015). Furthermore, the fact that a majority of the bovid long bones have a complete shaft circumference and $<1.4$ of the original length of the bone suggests that the bones likely under- 
went postmortem, post depositional sediment loading modification (Figures 18, 19). This static loading is also consistent with some of the hominin remains reported by L'Abbé et al. (2015).

The assemblage includes bones lying near each other that were in articulation during fossilization and bones that are broken in situ with the adjacent pieces lying near each other in the matrix. Examples of the former are the displacement of the cervical vertebrae (see Figure 14) and the aforementioned metatarsal and astragalus slightly displaced from the tibiae in Block 848 . These results support the suggestion that in addition to weathering, the assemblage was modified with sediment loading consistent with movement and flexion of the surrounding matrix (Villa and Mahieu, 1991). Despite the small sample size, the articulated bones, apparent lack of taxonomic skeletal element bias, and absence of taphonomically distinct marks from a biotic accumulating agent support the reconstruction of Malapa as a vertical cave opening, or death trap (Dirks et al., 2010; Val et al., 2015; L'Abbé et al., 2015).

The current bovid assemblage is consistent with complete animals entering the cave on their own, whether by accident or of their own volition, and were unable to escape. While it is a small sample size, the lack of compelling evidence for perimortem fractures is likely due to the suggestion that the substrate the animals fell on was not hard enough to cause breakages typical of a high impact fall. The hominins and fauna likely fell on a substrate of gravel, sand, and guano (Dirks et al., 2010; L'Abbé et al., 2015). The Malapa bovids may not have damaged their body significantly enough to demonstrate perimortem fractures, at least not recognizable perimortem fractures, but were still unable to leave the cave.

\section{CONCLUSIONS}

The Malapa bovid assemblage, while small, provides important contextual information about the bovids that are found associated with $A$. sediba. The taxonomic list overlaps with the taxa from other nearby sites despite the fact that the suite of bovids at Malapa is not found at any single site in the Cradle of Humankind. In addition, the recovered sample supports Gentry (1970) that the range of Makapania broomi is more widespread than the evidence currently suggests. While preliminary, the bovid remains suggest that the paleoenvironment of Malapa includes a mixture of grasslands and woodlands appropriate for browsing and a perma- nent water source, which is consistent with nearby hominin-bearing caves.

The preservation of partially articulated and closely associated bovid skeletons is unique at Malapa. With that said, the overall bovid sample size is quite small and, therefore, difficult to draw conclusions. At a minimum, we conclude that the bovid sample contributes to our understanding of the site formation processes acting at Malapa. In addition to the apparent lack of skeletal element bias, no evidence of a bone accumulating agent exists on the Malapa bovids. The bovid remains include a few specimens with perimortem trauma typically consistent with a fall while most of the assemblage exhibits surface damage and fracture patterns consistent with post depositional fractures. The breakage patterns, in particular, indicate abiotic, sediment loading likely affected the bones. Ultimately, the results of the taphonomic analyses suggest the bovids entered the cave and were buried in a similar manner to $A$. sediba (L'Abbé et al., 2015).

\section{ACKNOWLEDGEMENTS}

We would like to thank B. Zipfel of the University of Witwatersrand and S. Potze, and L. Kgasi of the the Ditsong National Museum of Natural History (formerly Transvaal Museum) for generously granting us access to their extant and fossil comparative collections. We would also like to thank $\mathrm{J}$. Adams, A. Gentry, and B. Brain for input on the paper. Finally, we appreciate the invaluable comments and suggestions from the reviewers. Funding was provided by the University of Witwatersrand and Loyola University Chicago.

\section{REFERENCES}

Adams, J.W. 2012. A revised listing of fossil mammals from the Haasgat cave system ex situ deposits (HGD), South Africa. Palaeontologia Electronica, 15.3.29A, 88p: palaeo-electronica.org/content/2012issue-3-articles/323-haasgat-hgd-assemblage.

Behrensmeyer, A.K. 1975. The taphonomy and paleoecology of Plio-Pleistocene vertebrate assemblages east of Lake Rudolf, Kenya. Bulletin of the Museum of Comparative Zoology, 146:1-573.

Blyth, E. 1863. Catalogue of the Mammalia in the museum of the Asiatic Society of Bengal. The Asiatic Society, Calcutta.

Brain, C.K. 1981. The Hunters or the Hunted? An Introduction to African Cave Taphonomy. The University of Chicago Press, Chicago, Illinois.

Brink, J.S. 1999. Preliminary report on a caprine from the Cape mountains, South Africa. Archaeozoologia, 10:11-26. 
Brink, J.S. 2005. The evolution of the black wildebeest, Connochaetes gnou, and modern large mammal faunas in central southern Africa. PhD Thesis, University of Stellenbosch, Stellenbosch, South Africa.

Brink, J.S. and Lee-Thorp, J.A. 1992. The feeding niche of an extinct springbok, Antidorcas bondi (Antelopinae, Bovidae), and its palaeoenvironmental meaning. South African Journal of Science, 88:227-229.

Brophy, J.K. 2011. Reconstructing the habitat mosaic associated with Australopithecus robustus: evidence from a quantitative morphological analysis of bovid teeth. Ph.D. Thesis, Texas A\&M University, College Station, Texas, USA.

Bunn, H.T. 1982. Meat-eating and human evolution: studies on the diet and subsistence patterns of PlioPleistocene hominids in East Africa. PhD Thesis, University of California, Berkeley, California, USA.

Davis, S. 1980. A note on the dental and skeletal ontogeny of Gazella. Israeli Journal of Zoology, 29:129134.

de Blainville, H. 1816. Su plusieurs espèces d'animaux mammifères, de l'ordre des Ruminants. Bulletin des sciences par la Société philomathique de Paris, 1816:73-82.

de Rochebrune, A. 1883. Faune de la Sénégambie. O. Doin, Paris.

de Ruiter, D.J. 2003. Revised faunal lists for Members 13 of Swartkrans, South Africa. Annals of the Transvaal Museum, 40:29-41.

de Ruiter, D.J., Sponheimer, M., Lee-Thorp, J.A. 2008. Indications of habitat association of Australopithecus robustus in the Bloubank Valley, South Africa. Journal of Human Evolution, 55:1015-1030.

de Ruiter, D.J., Pickering, R., Steininger, C.M., Kramers, J.D., Hancox, P.J., Churchill, S.E., Berger, L.R., and Backwell, L. 2009. New Australopithecus robustus fossils and associated U-Pb dates from Cooper's Cave (Gauteng, South Africa). Journal of Human Evolution, 56:497-513.

Dirks, P.H.D.M., Kibii, J.N., Kuhn, B.F., Steininger, C., Churchill, S.E., Kramers, J.D., Pickering, R., Farber, D.L., Mériaux, S.A., Herries, A.I.R., King, G.C.P., and Berger, L.R. 2010. Geological setting and age of Australopithecus sediba from southern Africa. Science, 328: 205-208.

Estes, R.D. 1992. The Behavior Guide to African Mammals: Including Hoofed Mammals, Carnivores, Primates. University of California Press. Berkeley, California.

Fernandez, M.H., and Vrba, E.S. 2006. Plio-Pleistocene climatic change in the Turkana Basin (East Africa): evidence from large mammal faunas. Journal of Human Evolution, 50:595-626.

Fortelius, M. and Solounias, N. 2000. Functional characterization of ungulate molars using the abrasion-attrition wear gradient: a new method for reconstructing paleodiets. American Museum Novitates, 3301:1-36.
Gentry, A.W. 1970. Revised classification for Makapania broomi Wells and Cooke (Bovidae, Mammalia). Palaeontologia Africana, 13:63-67.

Gentry, A.W. 1985. The Bovidae of the Omo group deposits, Ethiopia, p. 119-191. In Coppens, Y. and Howell, F.C. (eds.), Les Faunes Plio-Ple'istoce 'ne de la Basse Valle'e de l'Omo (E'thiopie). Tome 1: Pe'rissodactyles - Artiodactyles (Bovidae). CNRS, Paris.

Gentry, A.W. and Gentry, A. 1978. Fossil Bovidae (Mammalia) of Olduvai Gorge, Tanzania. Part I. Bulletin of the British Museum (Natural History) Geology, 29:289-446.

Gray, J.E. 1821. On the natural arrangement of vertebrose animals. London Medical Repository, 15:296310.

Gray, J.E. 1872. Catalogue of the ruminant Mammalia (Pecora, Linnaeus) in the British Museum. Trustees of the British Museum, London.

Haynes, G. 1983. Frequencies of spiral and green-bone fractures on ungulate limb bones in modern surface assemblages. American Antiquity, 48:102-114.

Hendey, Q., 1974. The late Cenozoic Carnivora of the southwestern Cape Province. Annals of the South African Museum, 63:1-369.

Henry, A.G., Ungar, P.S., Passey, B.H., Sponheimer, M., Rossouw, L., Bamford, M., Sandberg, P., de Ruiter, D.J., and Berger, L.R. 2012. The diet of Australopithecus sediba. Nature, 487:90-93.

Herries, A.I., Curnoe, C., and Adams, J.W., 2009. A multi-disciplinary seriation of early Homo and Paranthropus bearing palaeocaves in southern Africa. Quaternary International, 202:14-28.

L’Abbé, E.N., Symes, S.A., Pokines, J.T., Cabo, L.L., Stull, K.E., Kuo, S., Raymond, D.E., Randolph-Quinney, P.S., and Berger, L.R. 2015. Evidence of fatal skeletal injuries on Malapa Hominins 1 and 2. Scientific Reports, 5(15120):1-10.

Lacruz, R.S., Brink, J.S., Hancox, P.J., Skinner, A.R., Herries, A., Schmid, P., and Berger, L.R. 2002. Palaeontology and geological context of a middle Pleistocene faunal assemblage from the Gladysvale Cave, South Africa. Palaeontologia Africana, 38:99114.

Lestrel, P.E. 1989. Method for analyzing complex twodimensional forms: Elliptical Fourier Functions. American Journal of Human Biology, 1:149-164.

Luyt, C.J. and Lee-Thorp, J.A. 2003. Carbon isotope ratios of Sterkfontein fossils indicate a marked shift to open environments c. 1.7 Myr ago: research articles: human origins research in South Africa. South African Journal of Science, 99:271-273.

Madella, M., Alexandre, A., and Ball, T. 2005. International code for phytolith nomenclature 1.0. Annals of Botany, 96:253-260.

Moodley, Y. and Bruford, M.W. 2007. Molecular biogeography: towards an integrated framework for conserving pan-African biodiversity. PLoS One, 2:e454. doi:10.1371/journal.pone.0000454. 
Pallas, P. 1766. Miscellanea Zoologica. P. van Cleef, Hagae.

Pickering, R., Dirks, P.H.D.M., Jinnah, Z., de Ruiter, D.J., Churchill, S.E., Herries, A.I.R., Woodhead, J.D., Hellstrom, J.C., and Berger, L.R. 2011. Australopithecus sediba at $1.977 \mathrm{Ma}$ and implications for the origins of the genus Homo. Science, 333:1421-1423.

Piperno, D. 2006. Phytoliths: A Comprehensive Guide for Archaeologists and Paleoecologists. Lanham: AltaMira Press.

Reed, K.E. 1996. The paleoecology of Makapansgat and other African Plio-Pleistocene hominid localities. PhD Thesis, State University of New York, Stony Brook, New York, USA.

Reynolds, S.C. and Kibii, J.M. 2011. Sterkfontein at 75: review of palaeoenvironments, fauna and archaeology from the hominin site of Sterkfontein (Gauteng Province, South Africa). Palaeontologia Africana, 46:59-88.

Schwarz, E. 1932. Neue diluviale Antilopen aus Ostafrika. Zentralblatt für Mineralogie, Geologie und Paläontologie B, 1932:1-4.

Scott, K.M. 1985. Allometric trends and locomotor adaptations in the Bovidae. Bulletin of the American Museum of Natural History, 197:197-288.

Sponheimer, M., Reed, K., and Lee-Thorp, J.A. 1999. Combining isotopic and ecomorphological data to refine bovid paleodietary reconstruction: a case study from the Makapansgat Limeworks hominin locality. Journal of Human Evolution, 36:705-718.

Sundevall, C. 1847. Methodisk öfversigt af Idislande djuren, Linnés Pecora. Kongliga Vetenskaps Ajademiens Handlinger för år, 1847:1-330.

Suwa, G., Nakaya, H., Asfaw, B., Saegusa, H., Amzaye, A., Kono, R.T., Beyene, Y., and Katoh, S., 2003. PlioPleistocene terrestrial mammal assemblage from Konso, southern Ethiopia. Journal of Vertebrate Paleontology, 23: 901-916.

Swanepoel, E. and Steyn, M. 2011. Robusticity of Bovidae skeletal elements from southern Africa and their potential in species identification. Annals of the Ditsong National Museum of Natural History, 1:41-52.

Talbot, L.M. and Talbot, M.H. 1963. The wildebeest in Western Masailand, East Africa. Wildlife Monograph, 12:1-88.
Val, A.M.S., Dirks, P.H.G.M., Backwell, L.R., d'Errico, F., and Berger, L.R. 2015. Taphonomic analysis of the faunal assemblage associated with the hominins (Australopithecus sediba) from the Early Pleistocene cave deposits of Malapa, South Africa. PLoS ONE, 10:e0126904. doi:10.1371/journal.pone.0126904.

van der Merwe, N.J., Thackeray, J.F., Lee-Thorp, J.A., Luyt, J. 2003. The carbon isotope ecology and diet of Australopithecus africanus at Sterkfontein, South Africa. Journal of Human Evolution, 44:581-597.

van Hoepen, E. 1932. Voorlopige beskrywing van Vrystaatse soogdiere. Paleontologiese Navorsing van die Nasionale Museum Bloemfontein, 2:63-65.

Villa, P. and Mahieu, E., 1991. Breakage patterns of human long bones. Journal of Human Evolution, 21:27-48.

Vrba, E. 1974. Chronological and ecological implications of the fossil Bovidae at the Sterkfontein australopithecine site. Nature, 250:19-23.

Vrba, E. 1976. The fossil Bovidae of Sterkfontein, Swartkrans and Kromdraai. Transvaal Museum Memoir, 21. Transvaal Museum, Pretoria.

Vrba, E. 1995. The fossil record of African antelopes (Mammalia, Bovidae) in relation to human evolution and paleoclimate, p. 385-424. In Vrba, E., Denton, G., Burckle, L., and Partridge, E. (eds.), Paleoclimate and evolution, with emphasis on human origins. Yale University Press, New Haven.

Wells, L. and Cooke, H. 1956. Fossil Bovidae from the Limeworks Quarry, Makapansgat, Potgeitersrus. Palaeontologia Africana, 4:1-55.

White, T.D. 1992. Prehistoric Cannibalism at Mancos 5MTUMR-2346. Princeton University Press, Princeton, New Jersey.

White, T.D. and Harris, J.M. 1977. Suid evolution and correlation of African hominid localities. Science, 198:13-21.

Wolfe, C. A., Lestrel, P. E. and Read, D. W. EFF23 2-D and 3-D Elliptical Fourier Functions. Software Description and User's Manual. PC/MS-DOS Version 4.0 (December 1999) 216pp. 